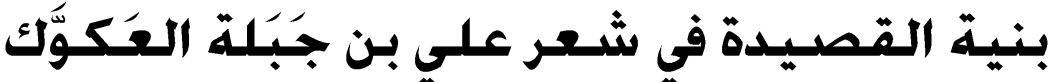

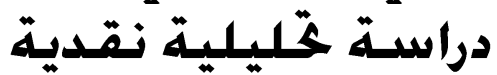 \\ إعداد
}

د. محمل زذوق الحسن

الأستاذ المساعد بكلية اللغة العربية

قسم الدراسات الأدبية والنقدية

جامعة أم درمان الإسلامية

تُعلُّ بنية القصيدة من الموضوعات المهمة في النقد العربي القديم فقلما خهــلا

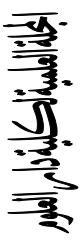

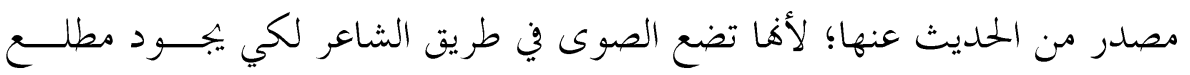

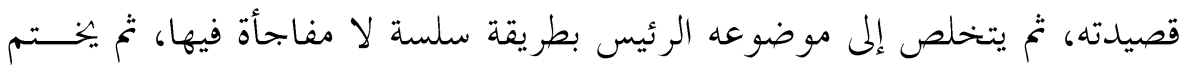

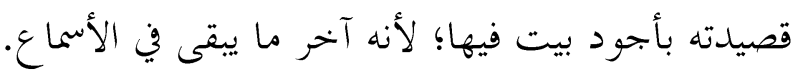

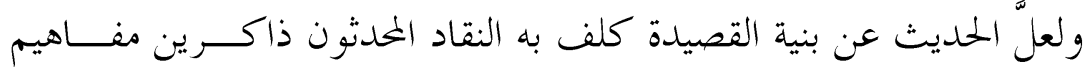

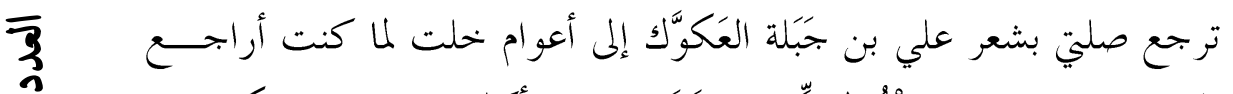

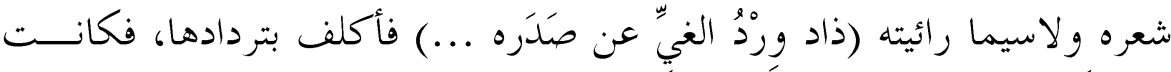

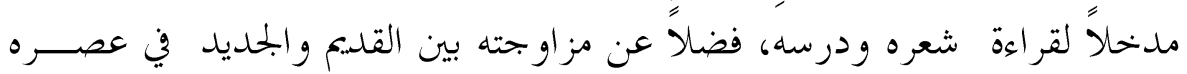

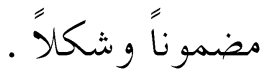

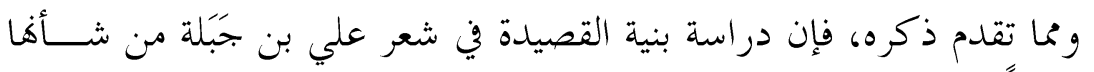

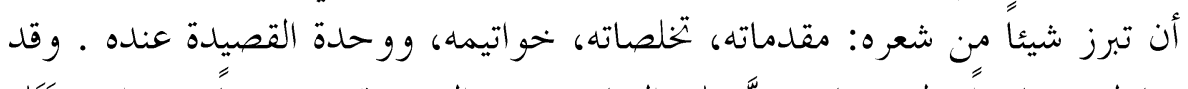

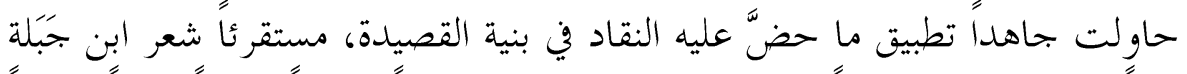

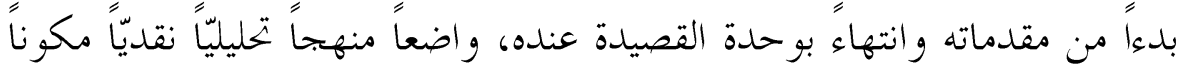

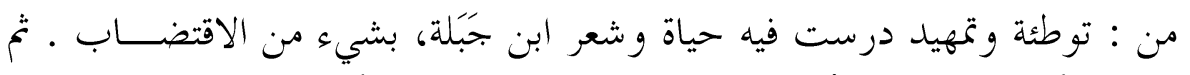

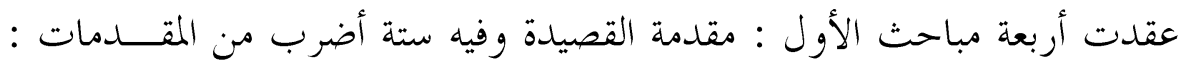

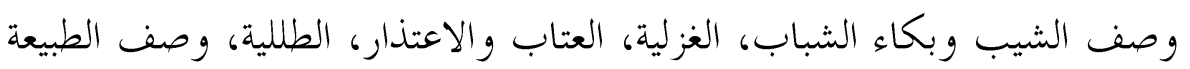

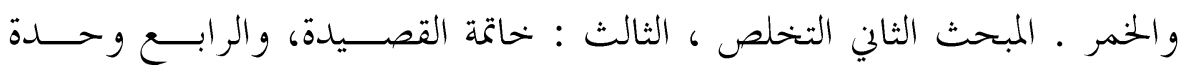

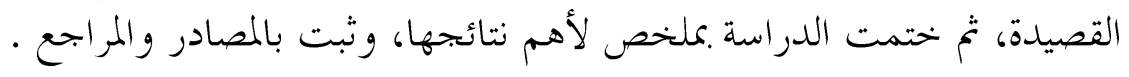




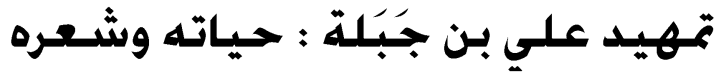

أولاً : حياته :

هو علي بن جَبَلة بن مسلم بن عبدالرحمن، من أبناء الشيعة الخراسانية يكني

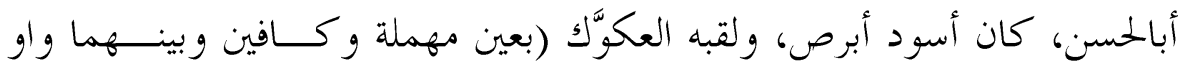

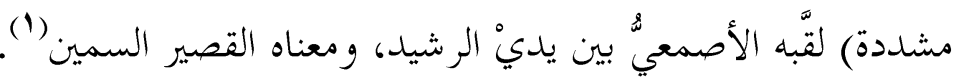

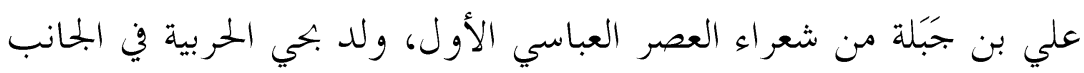

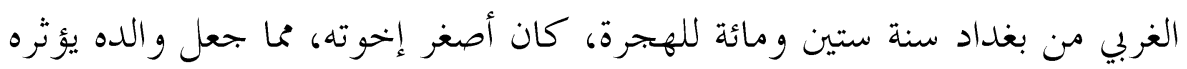

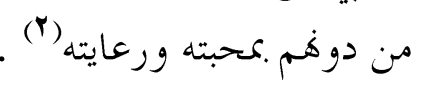
اختلف الرواة في فقده لبصره اختلافاً بيّناً، فمن قائل إنه ولد أكمه مكفوفاً

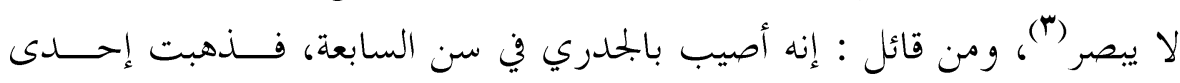

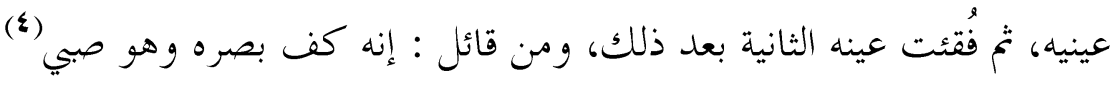

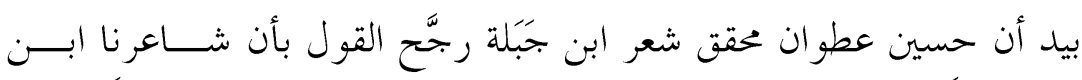

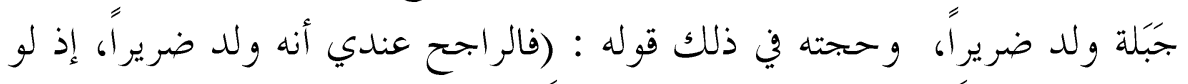

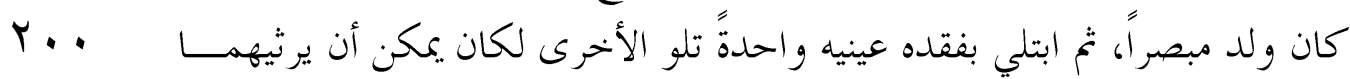

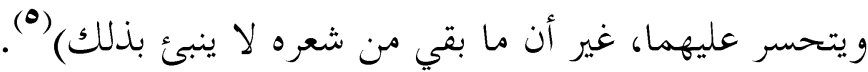

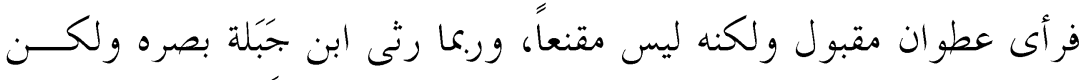

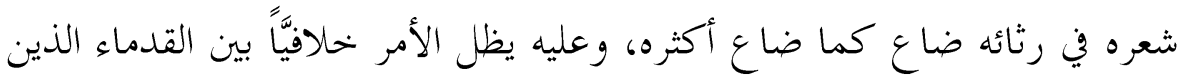

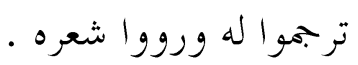

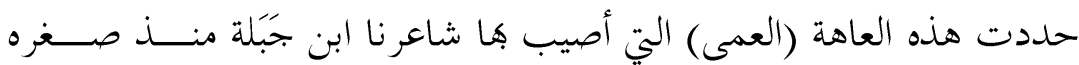

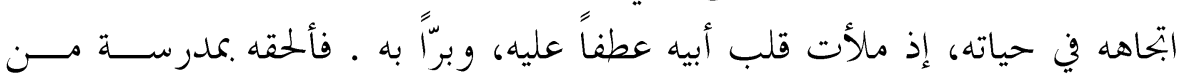

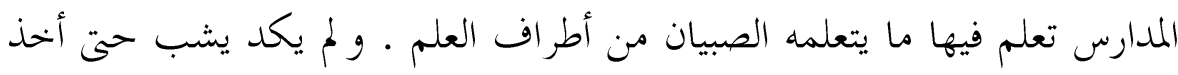

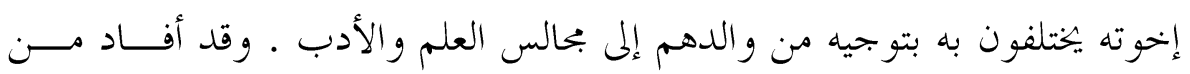

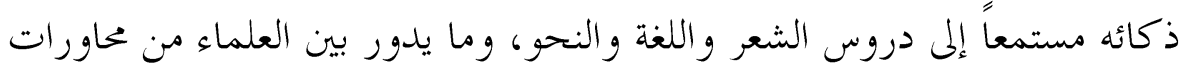

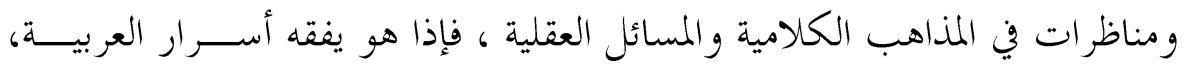

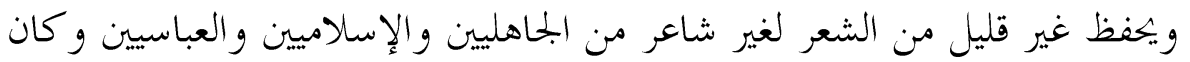

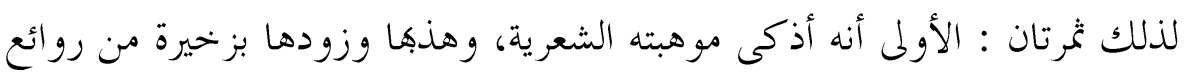




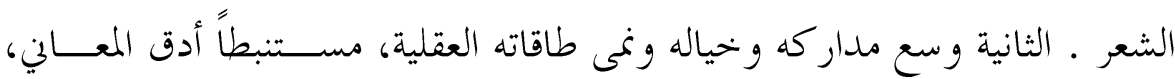

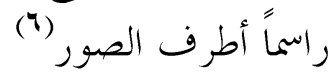

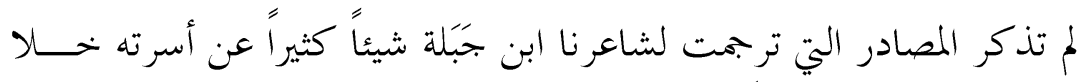

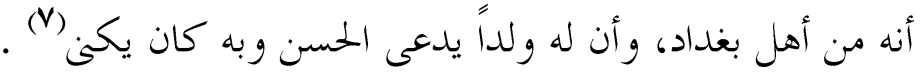

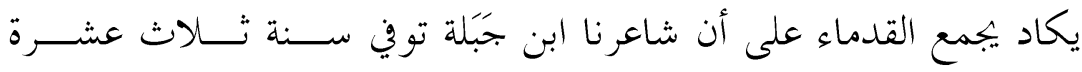

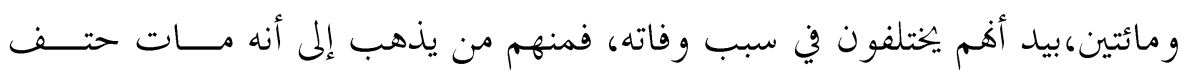

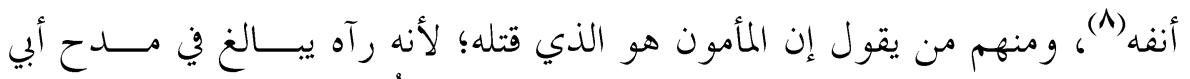

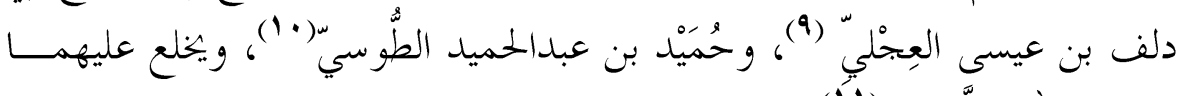

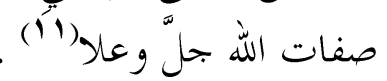

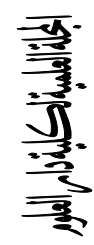

ولعلَّ المأمون تحامى شاعرنا ابن جَبَلة وجفاه وضيق عليه لأسباب سياسـية

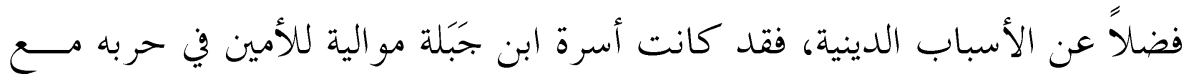

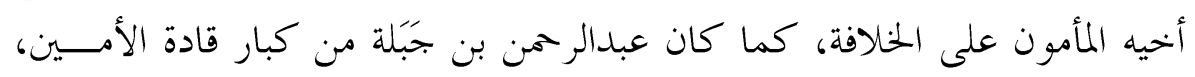

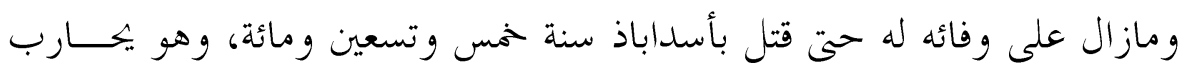

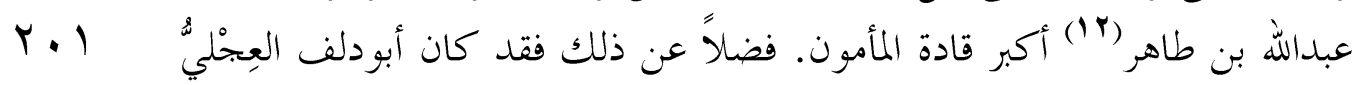

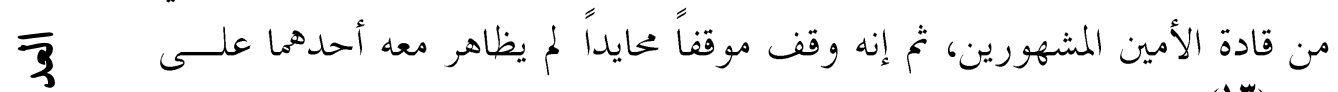

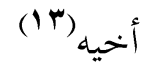

\section{ثانياً : شعـره :}

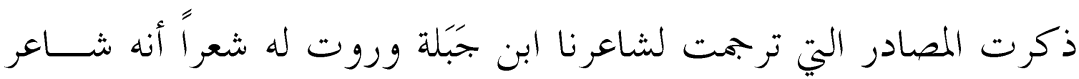

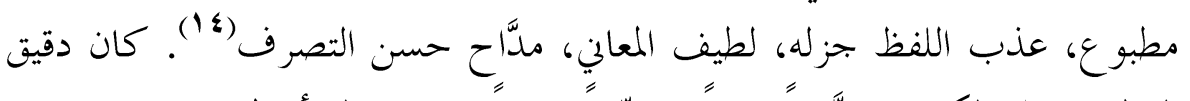

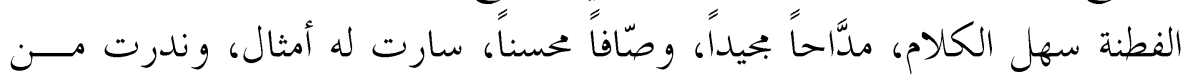

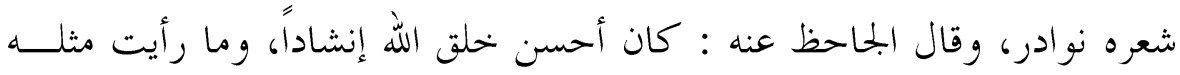

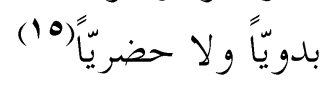

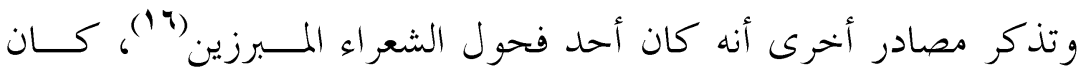

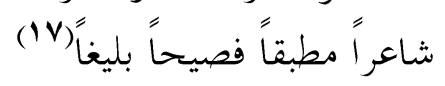

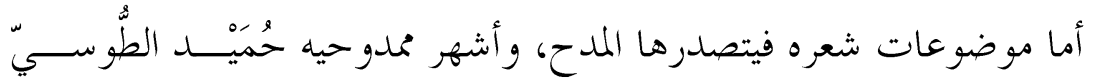

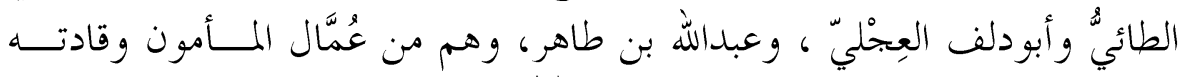

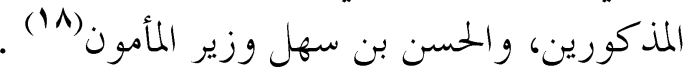




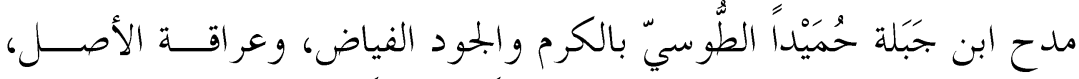

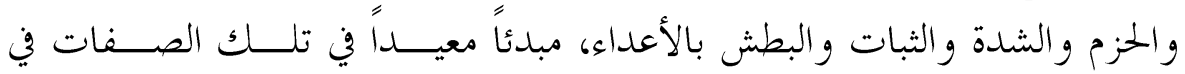

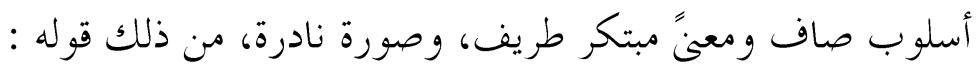

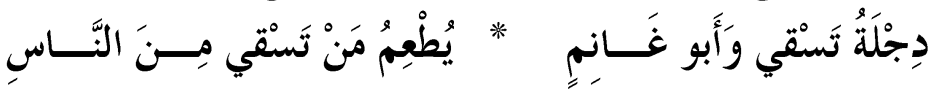

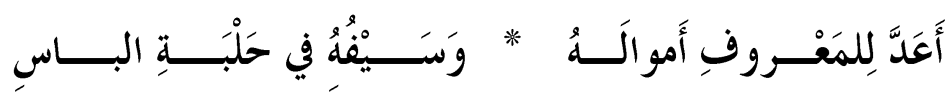

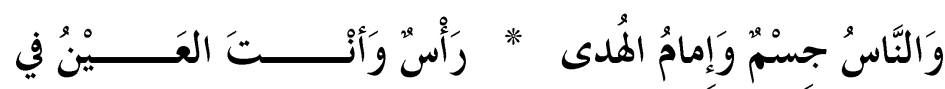

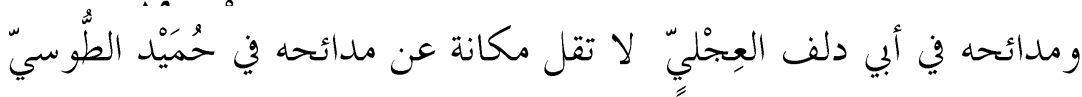

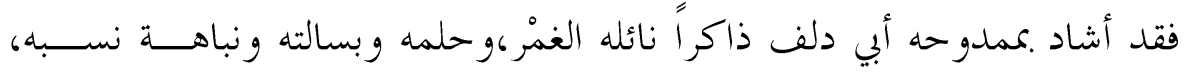

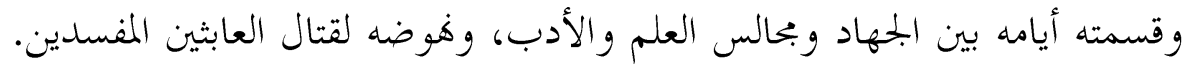

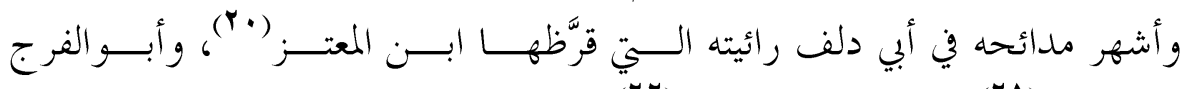

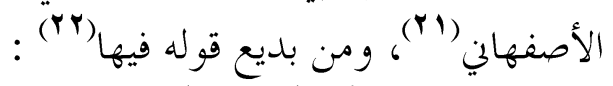

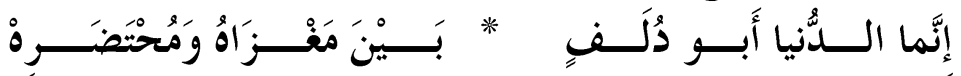

$r \cdot r$

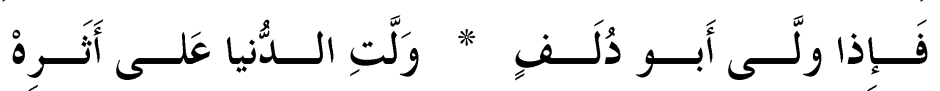

$\overline{3}$
3
2

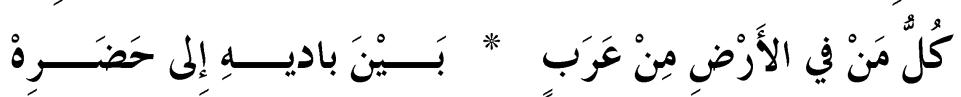

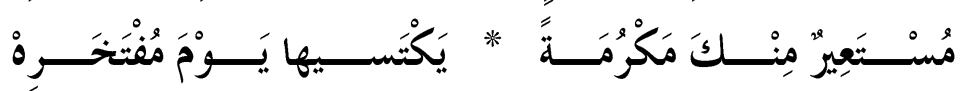
حاول شاعرنا ابن جَبَلة مدح الملوك، ففي أخباره أنه امتدح الرشيد بقصيدة

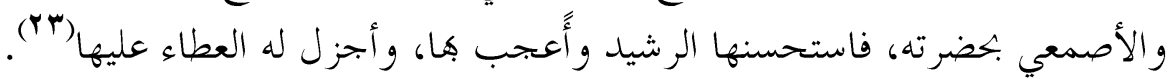

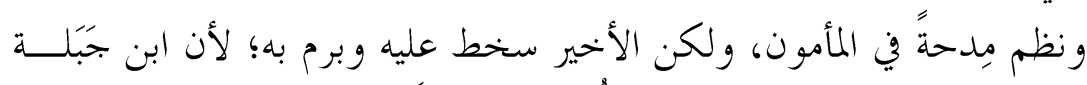

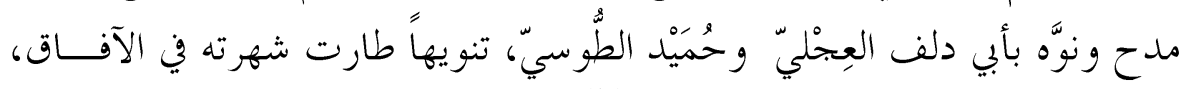

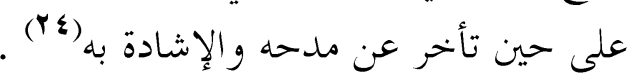

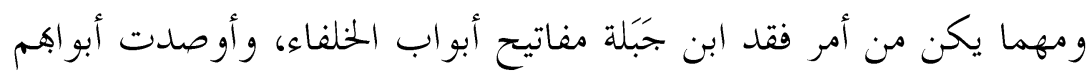

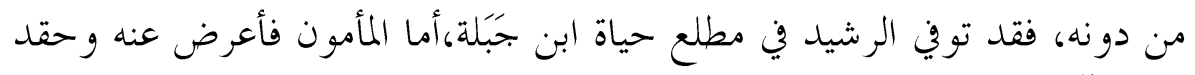
عليه (ro) 


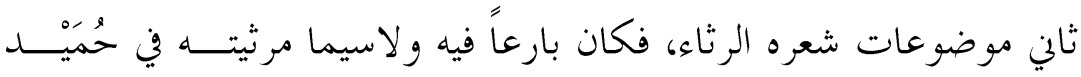

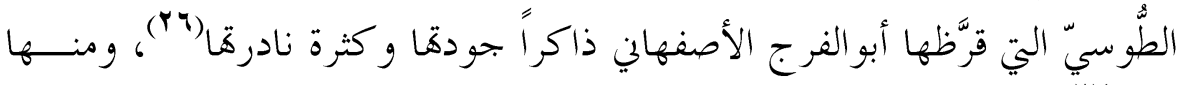

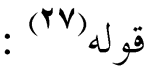

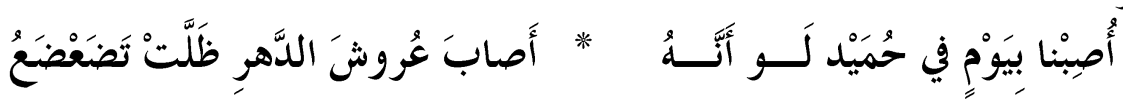

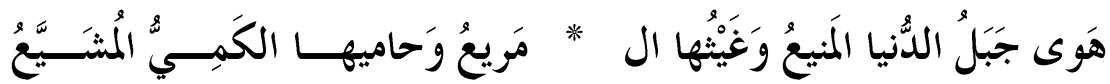

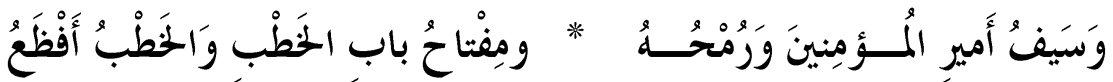

ثالث موضوعات شعره الهجاء، ويأخذ عنده شكل المقطوعة القصيرة مماثلاً

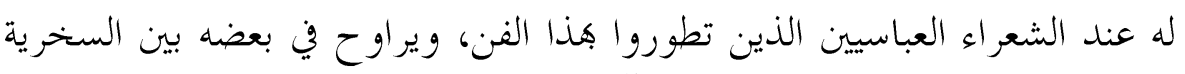

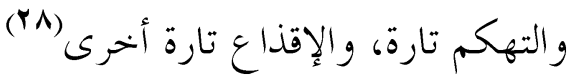

牙

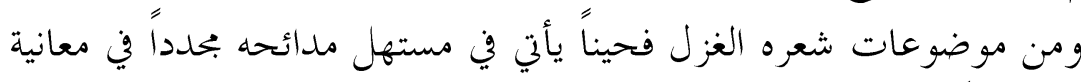

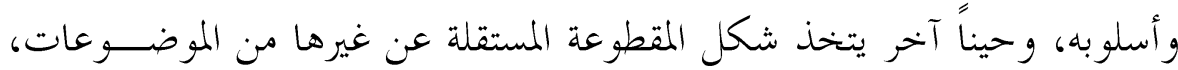

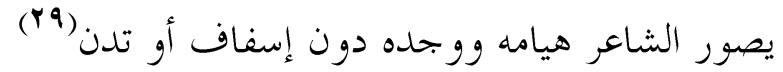

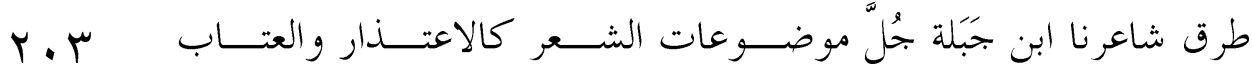
والوصف. ففي الاعتذار والعتاب يستلهم عقله الخصب، وذهنه الثاقب، لاستلال

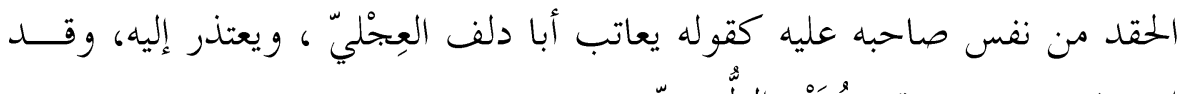

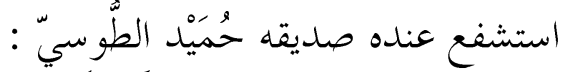

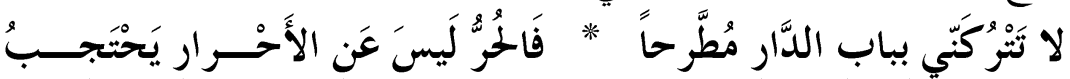

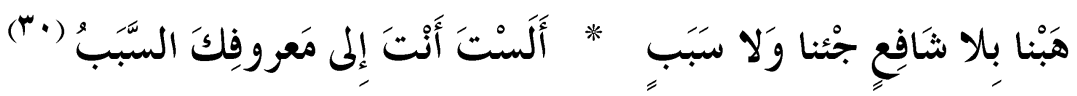

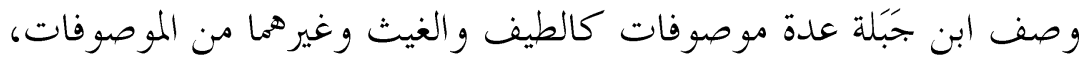

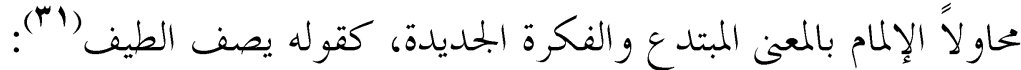

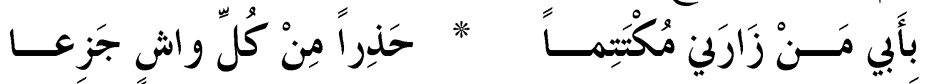

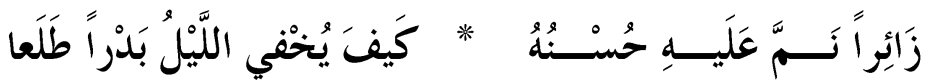

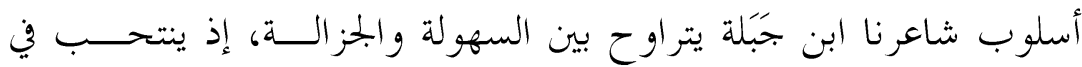

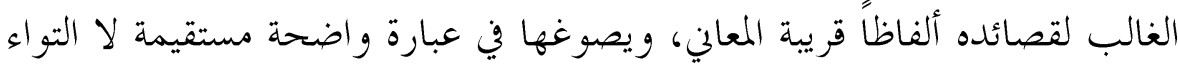

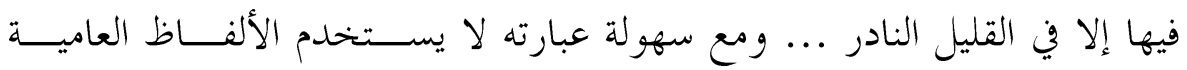


والعبارات الشعبية، بل يرتفع دائماً عنها، ويمرص على اللغة الفصيحة والأساليب الناصعة المتينة .

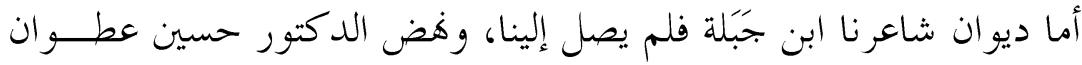

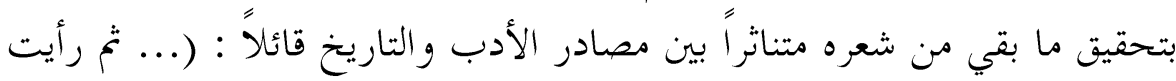

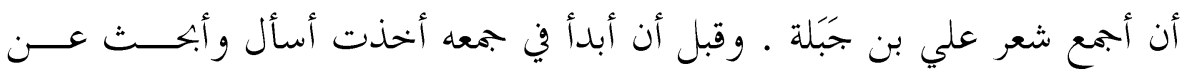

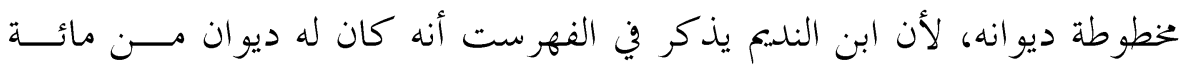

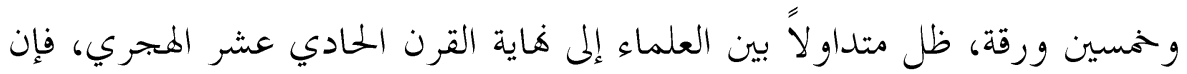

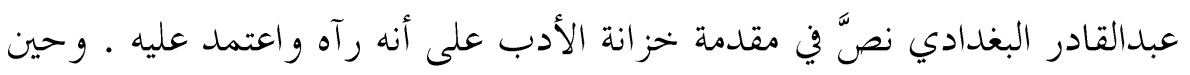

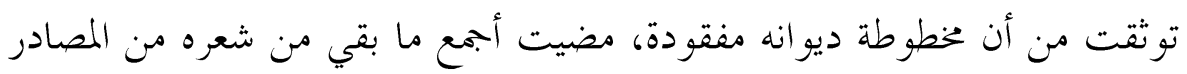

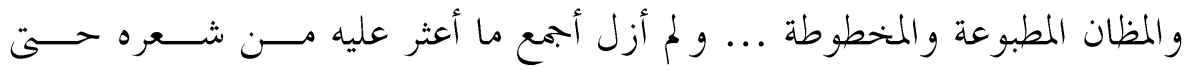

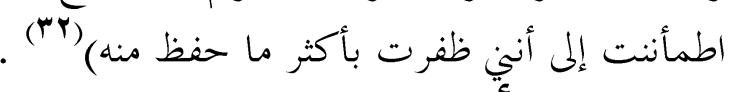

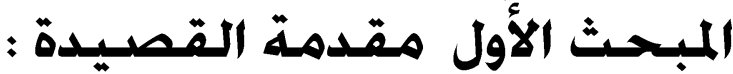

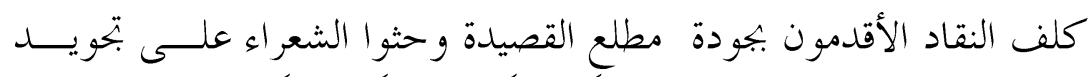

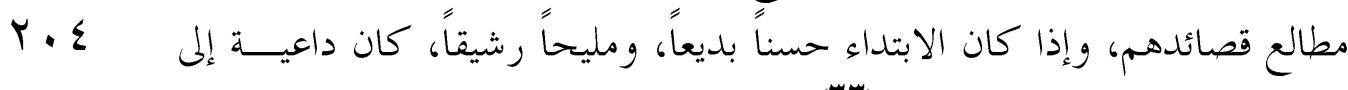

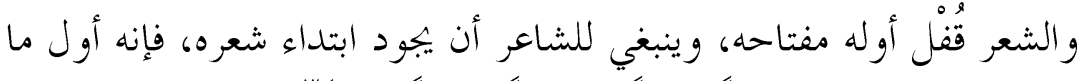

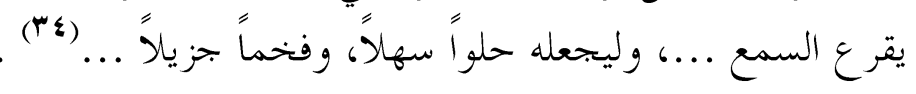

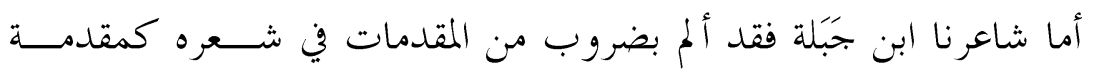

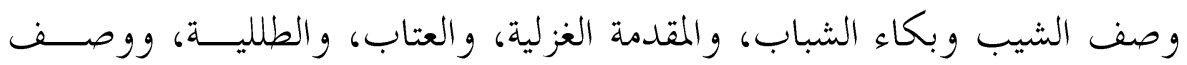

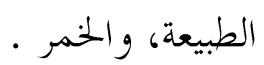
أ- مقدمة وصف الثيب وبكاء الثباب :

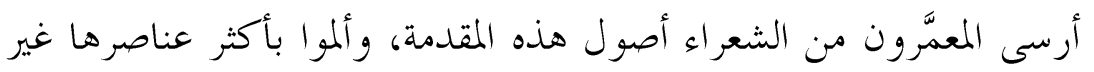

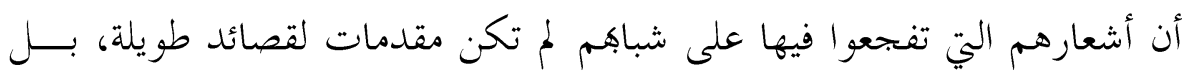

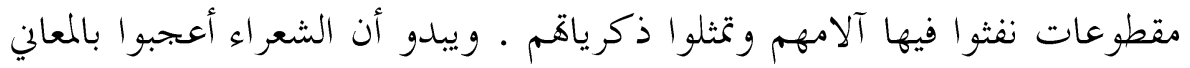

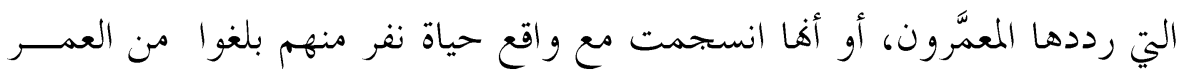




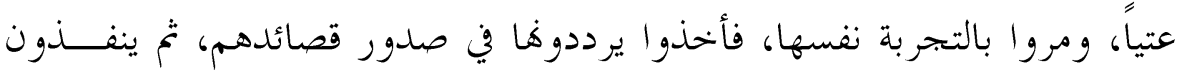

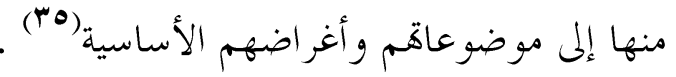

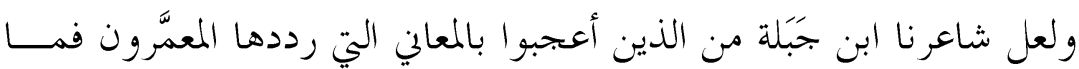

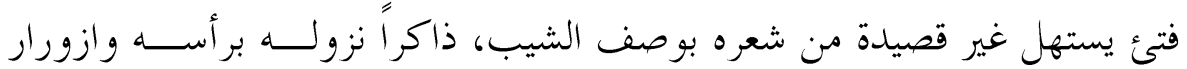

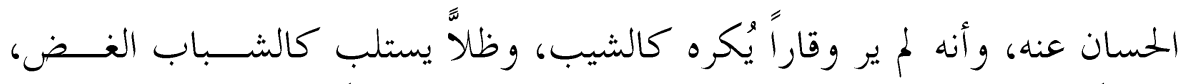

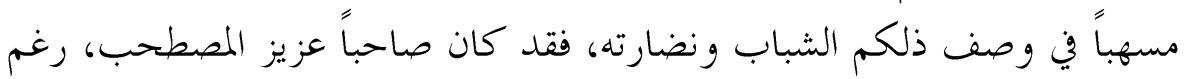

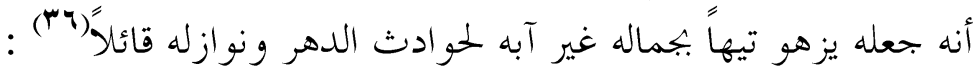

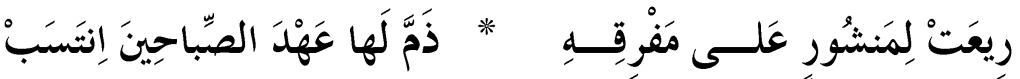

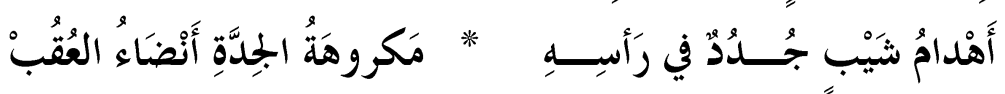

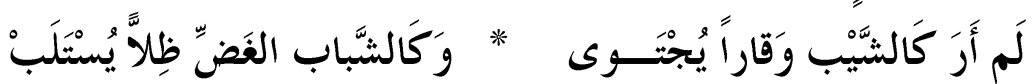

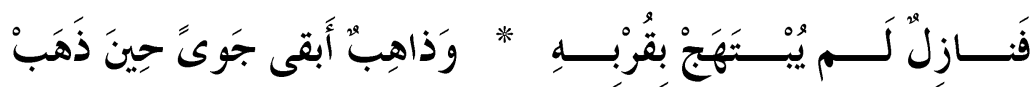

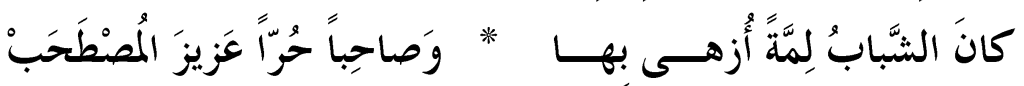

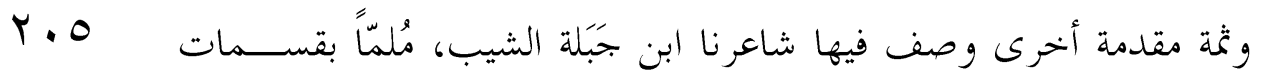

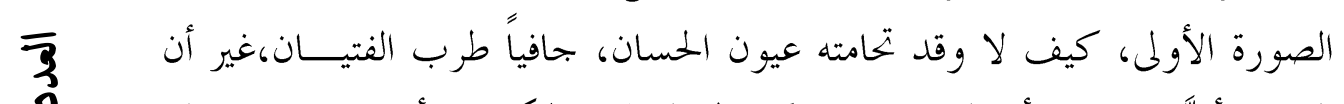

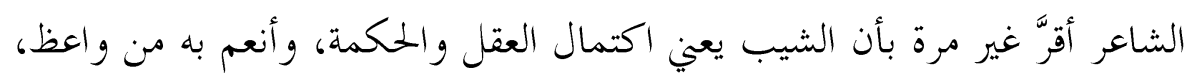

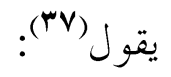

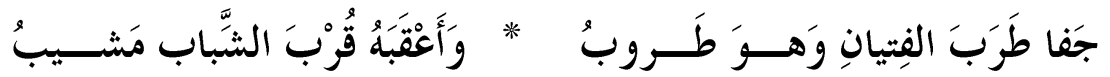

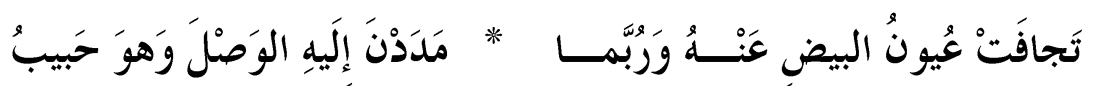

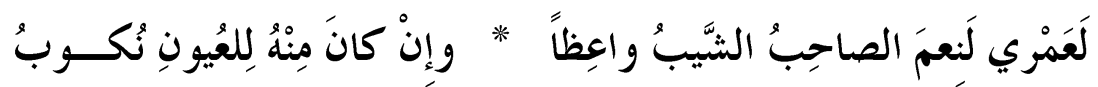

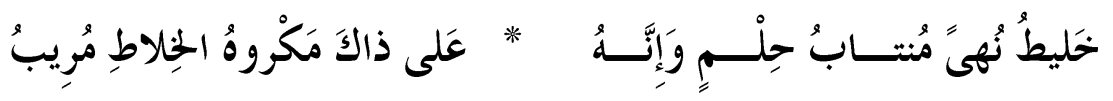

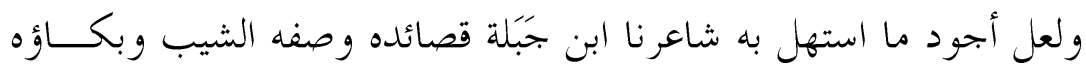

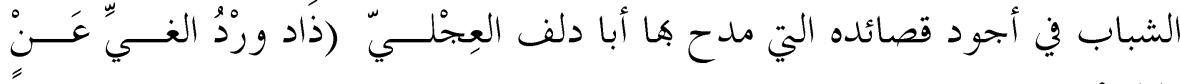

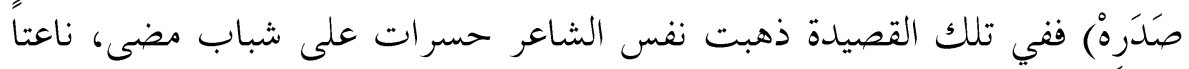

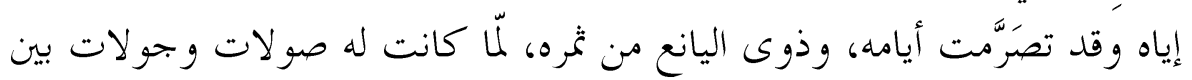


الفتيات النافرات. بيد أن الحسر ات المتتابعات لا تُجدي نفعاً في استرجاع شـــباب

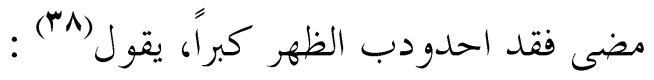

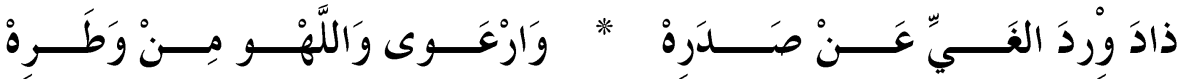

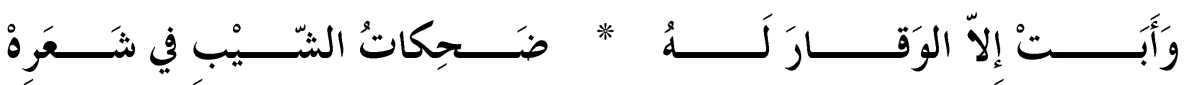

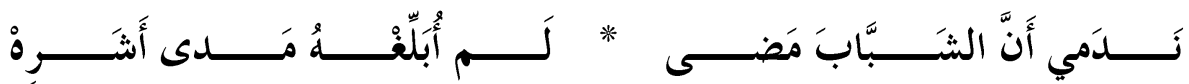

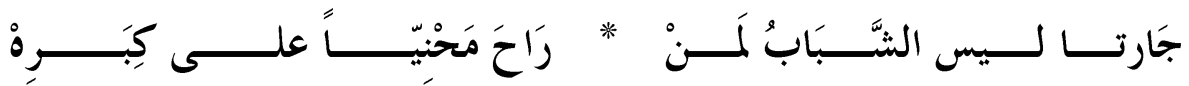

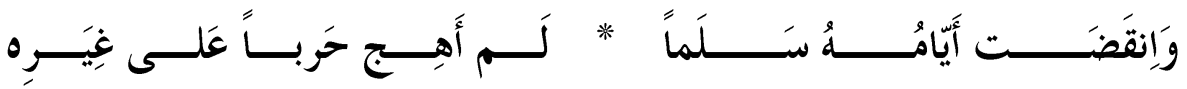

ما انفك ابن جَبَلة يصف الشيب في مفتتح قصائده، قائلاًُ (هa) :

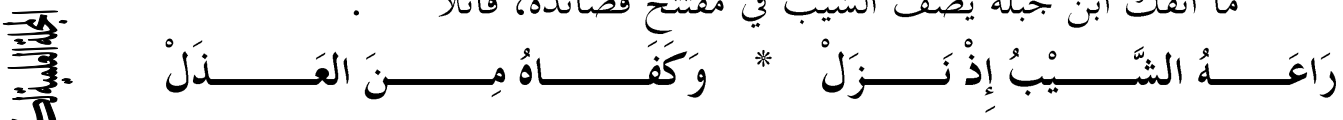

步

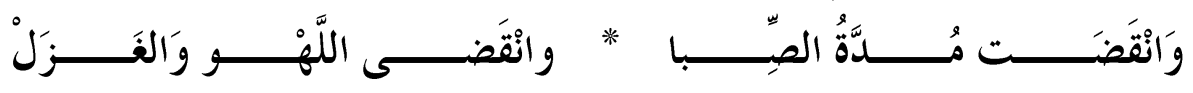

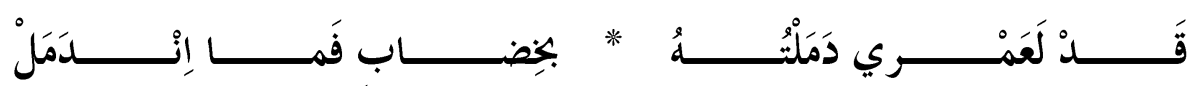

$r \cdot T$

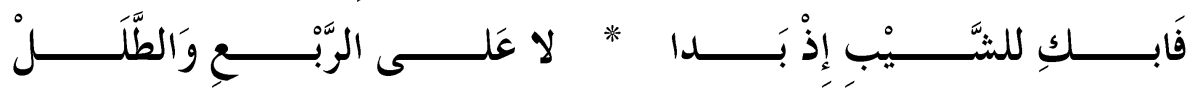

$\overline{3}$
3
2

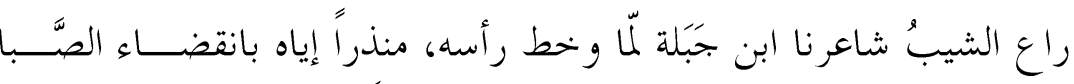

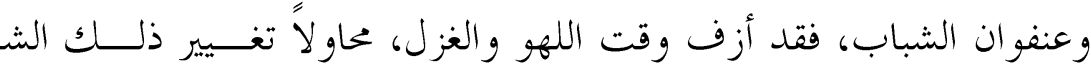

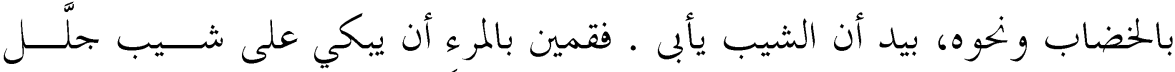

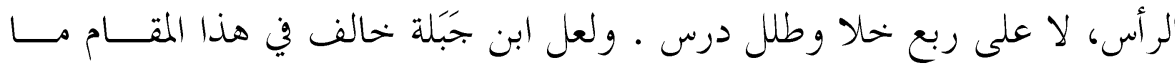

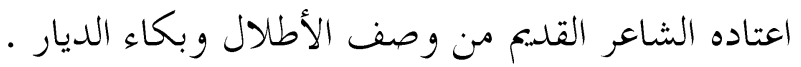

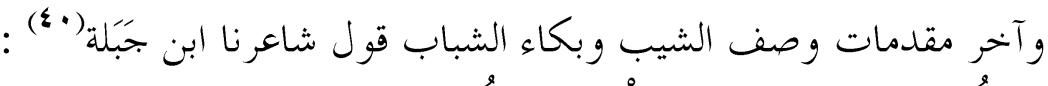

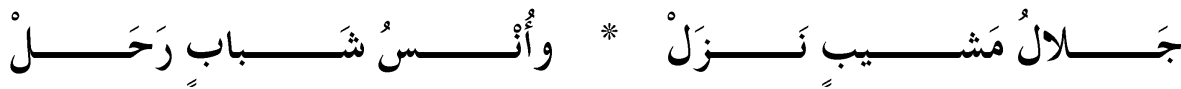

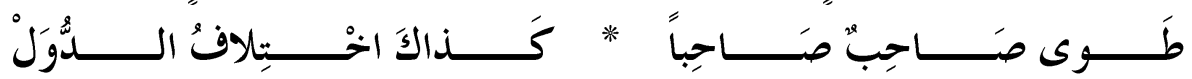

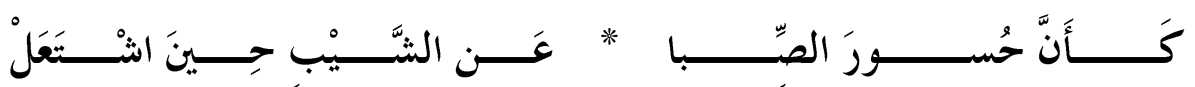

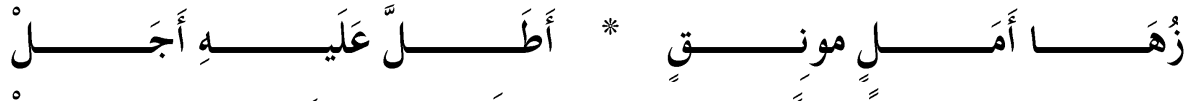

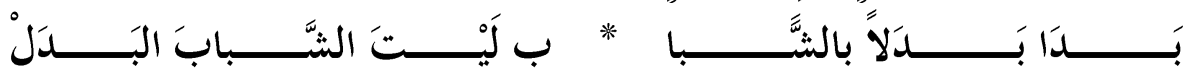




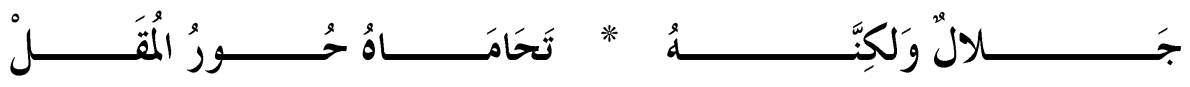

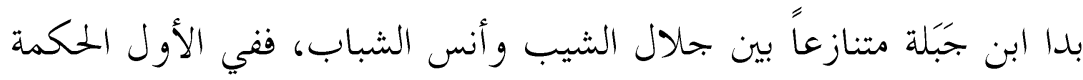

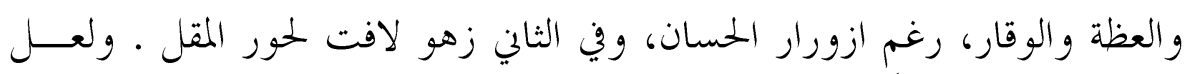

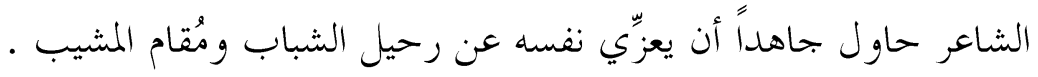

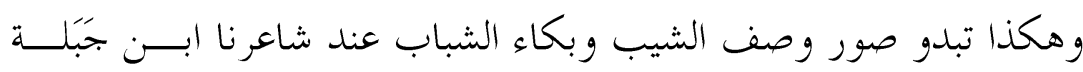

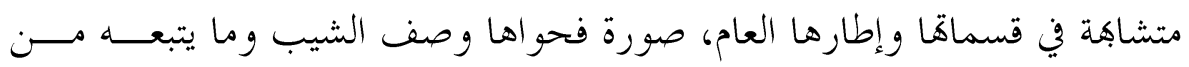

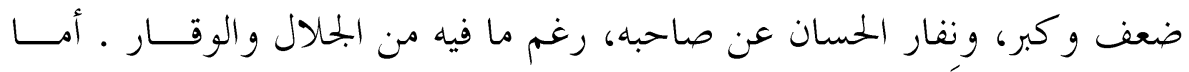

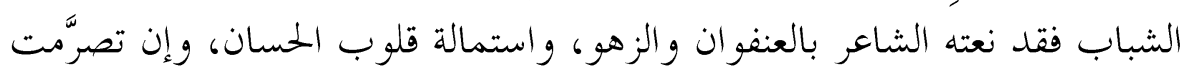

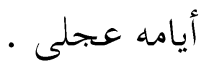

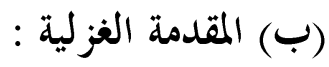

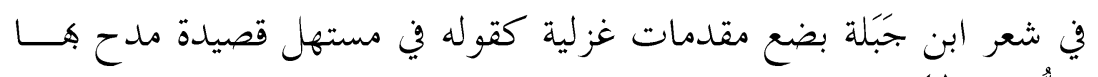

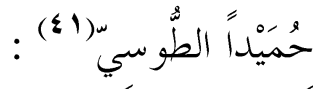

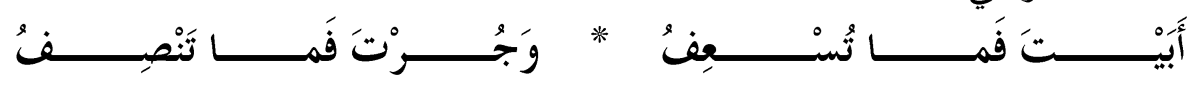

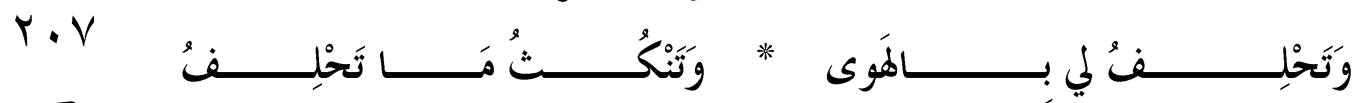
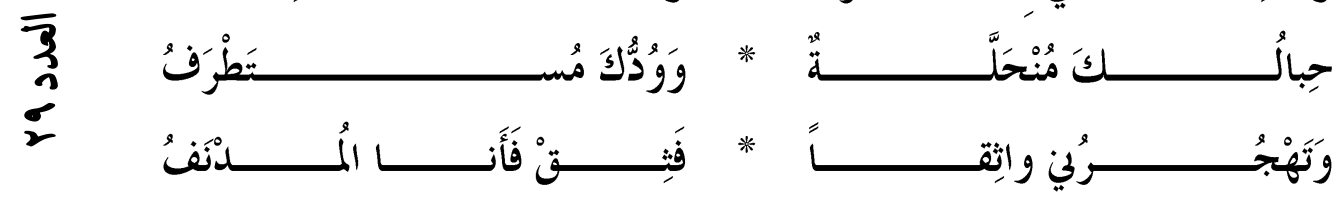

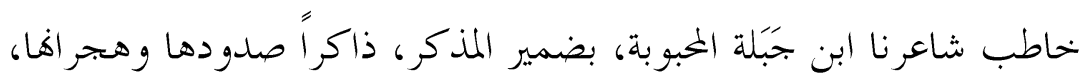

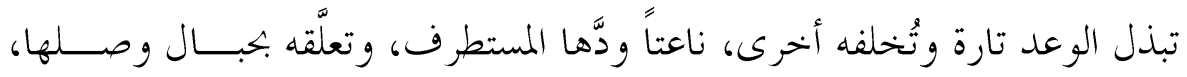

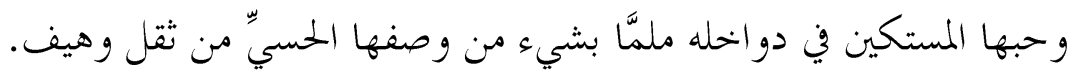

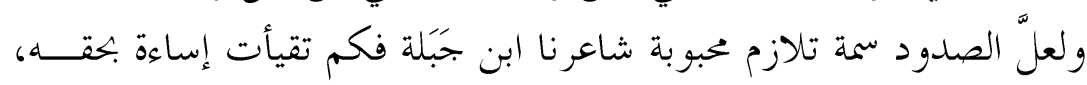

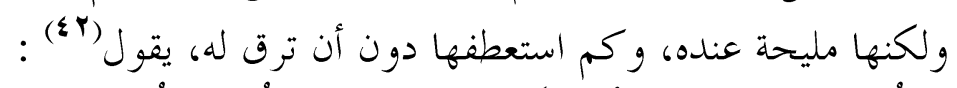

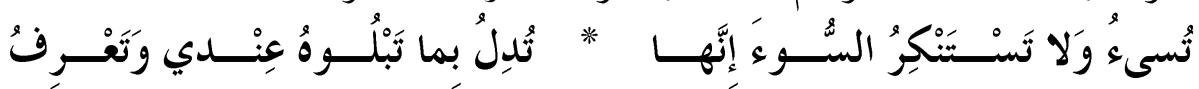

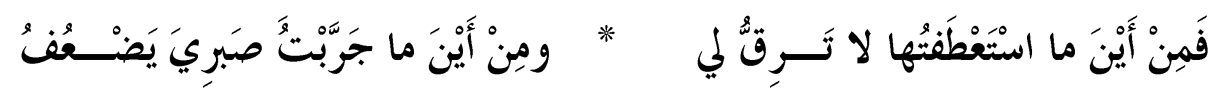

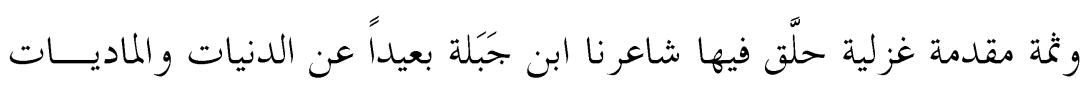

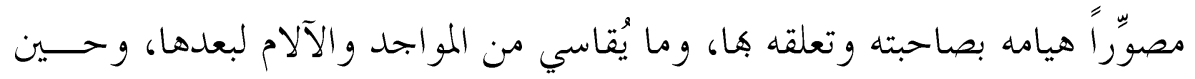




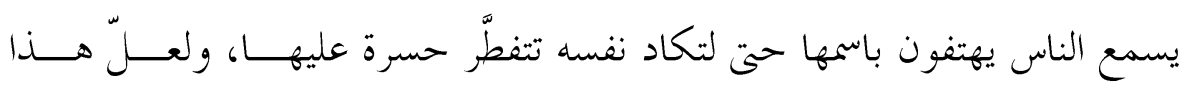

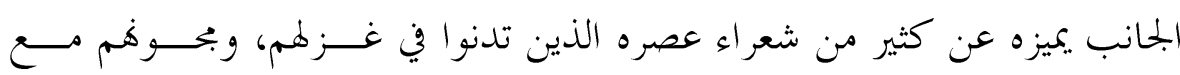

$$
\begin{aligned}
& \text { الجو اري و القيان (rاء) } \\
& \text { يقول ابن جَبَلة (§ §) : }
\end{aligned}
$$

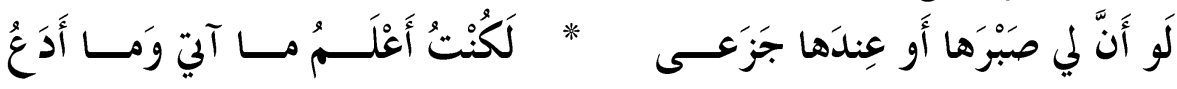

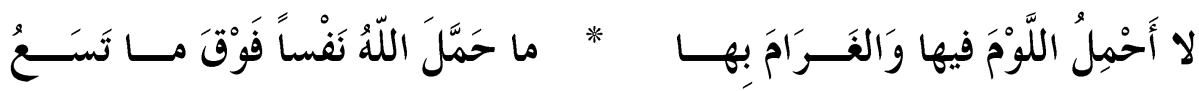

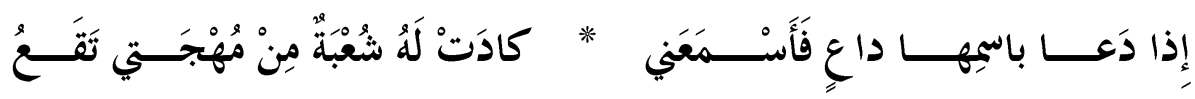
وهذه المقدمات الغزلية آنفة الذكر ألمت بغير قليل من حق النسيب الــذي

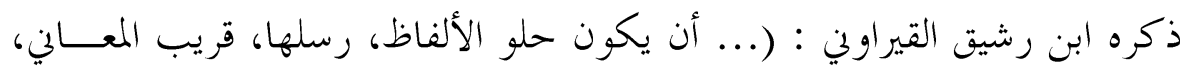

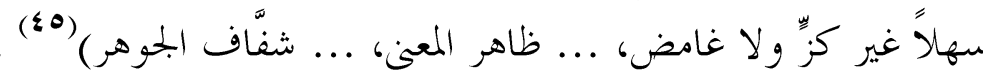

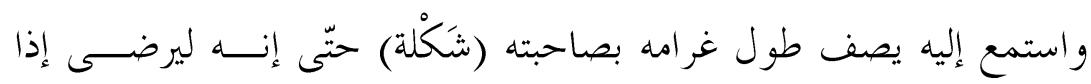

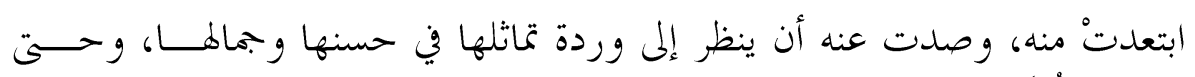

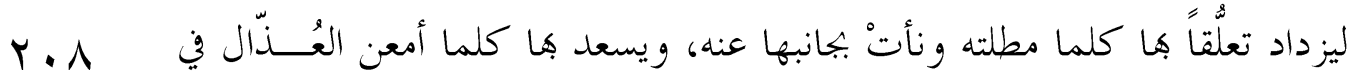

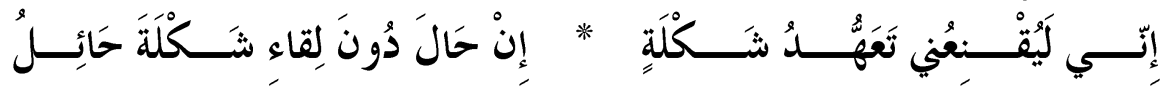

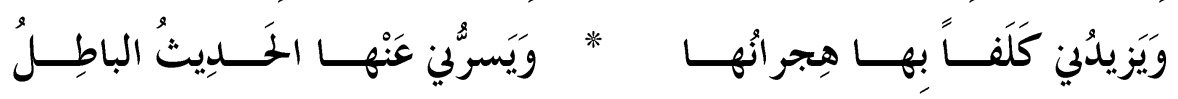

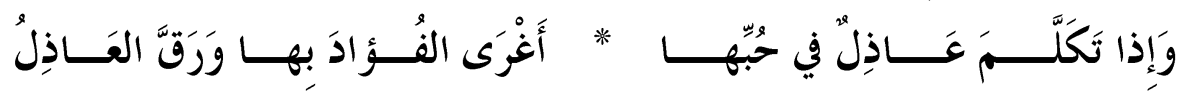
ومهما يكن من شيء، بدت المقدمات الغزلية عند شاعرنا ابن جَبَلة مفعمة

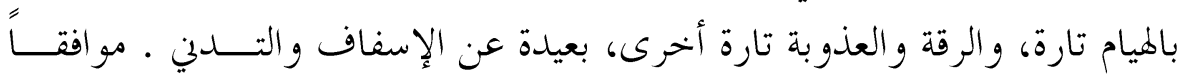

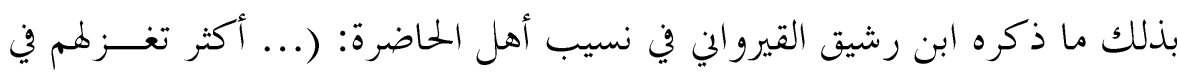

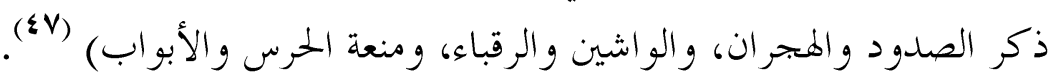

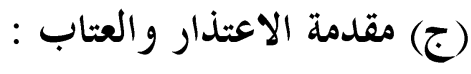

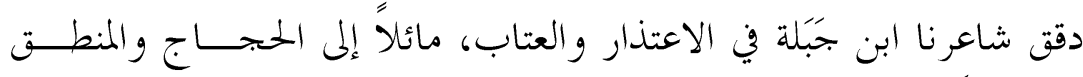

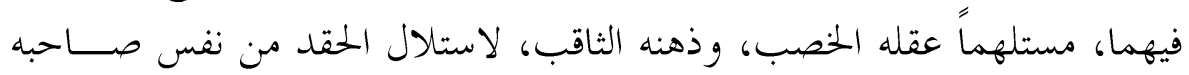


عليه، وبتحيد ما بينهما من المحبة والأُلفة، كقوله يعاتب أبا دلف العِجْليّ ، و يعتذر

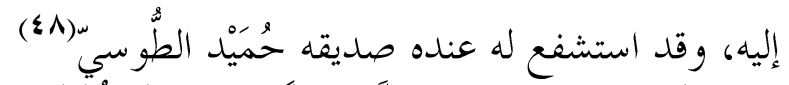

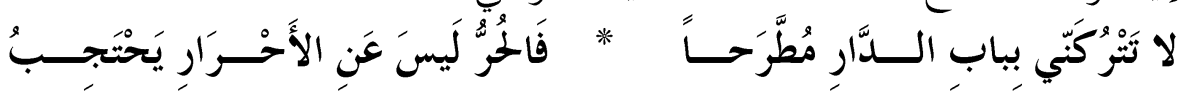

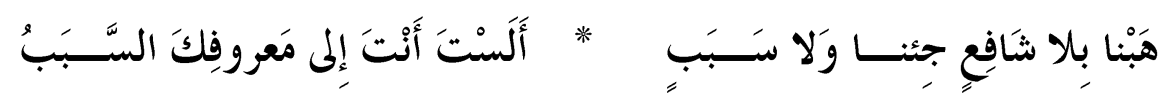

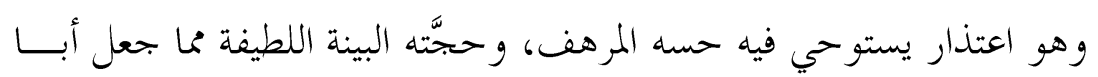

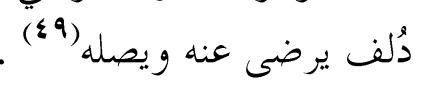

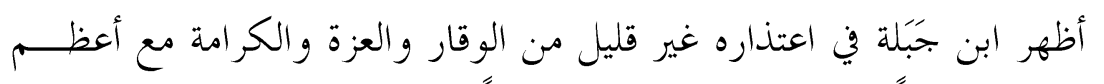

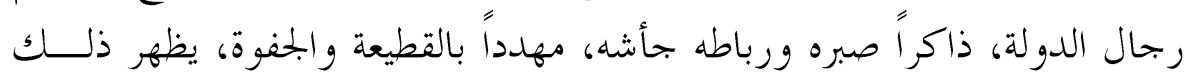

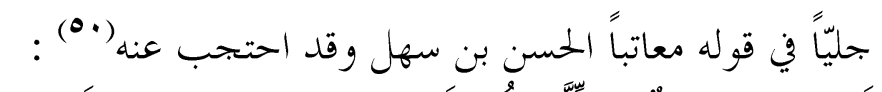

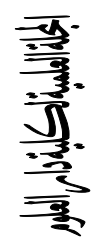

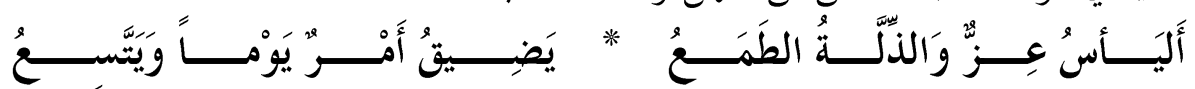

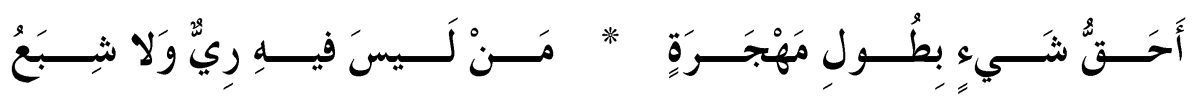

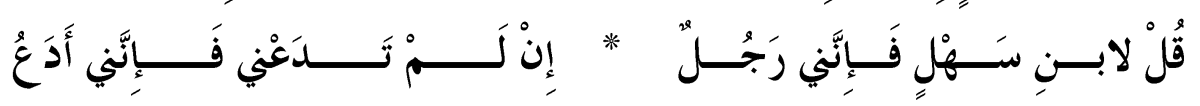

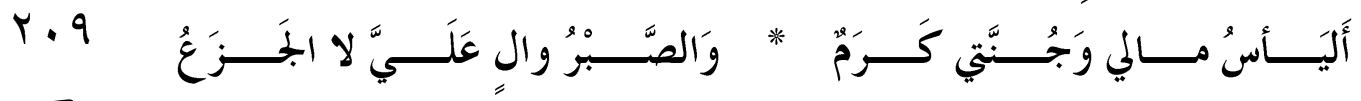

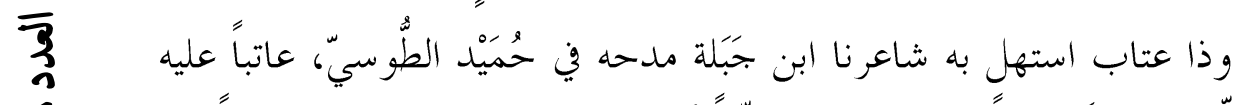

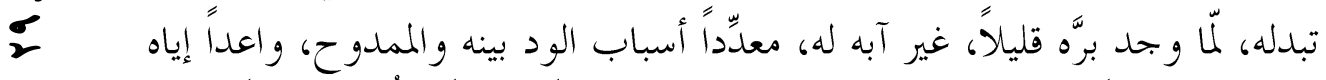

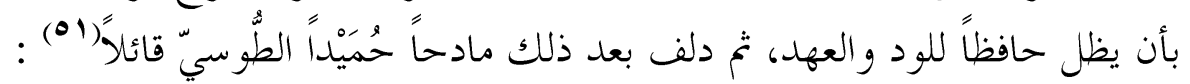

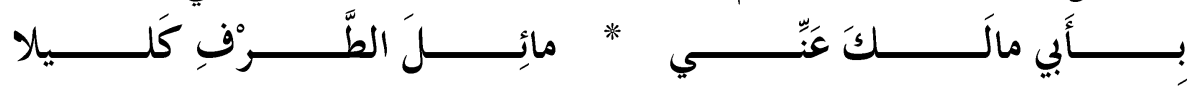

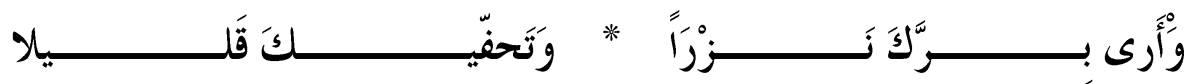

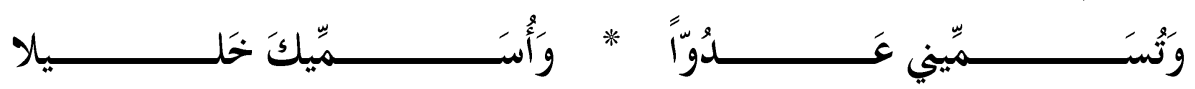

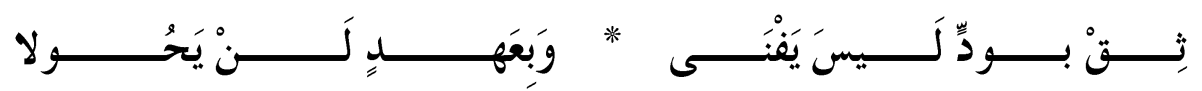

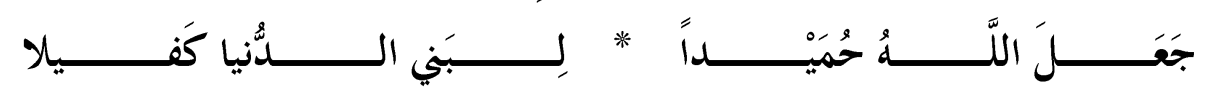

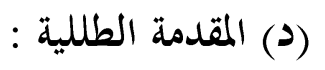

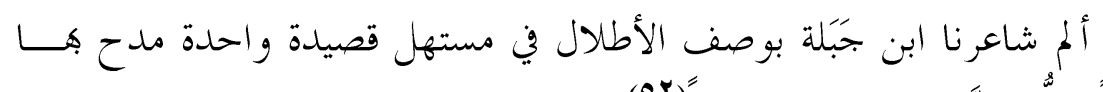

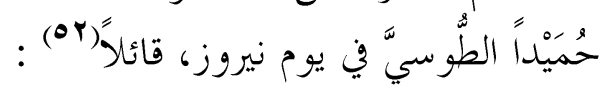



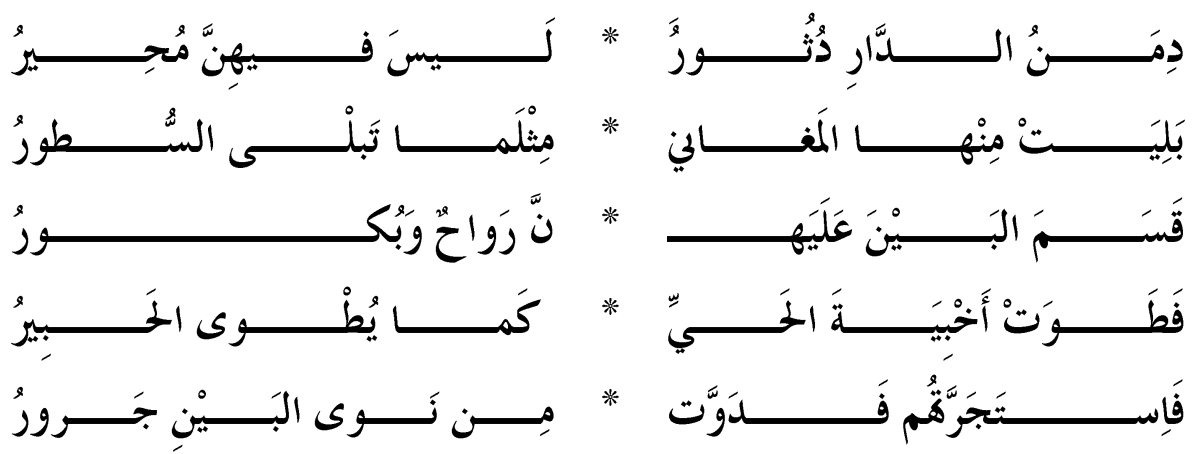

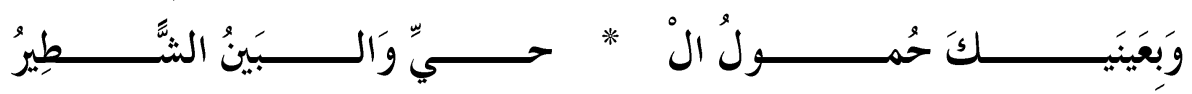

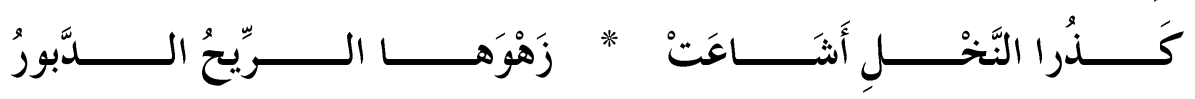

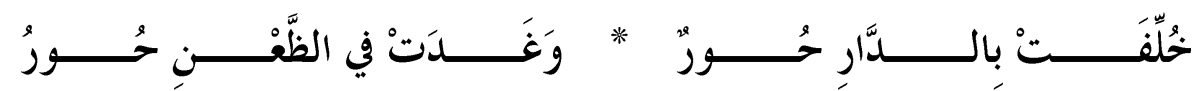

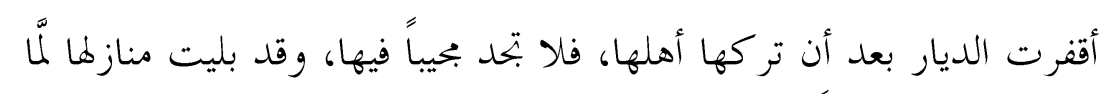

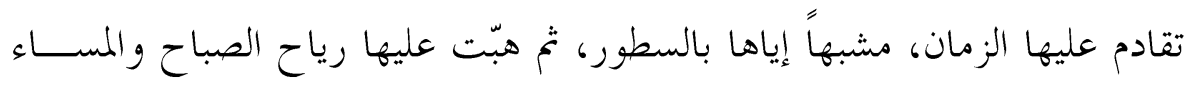

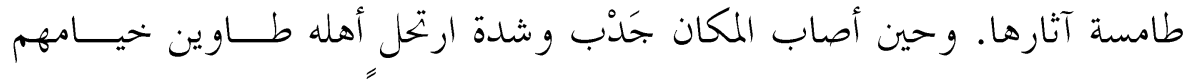

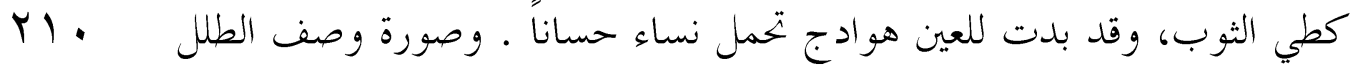

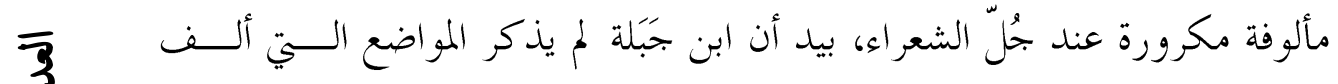

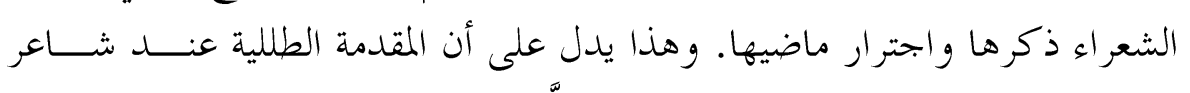

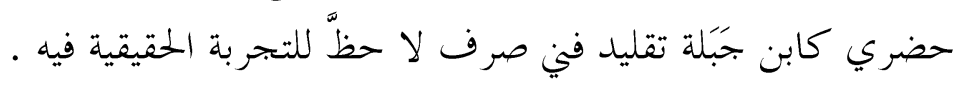

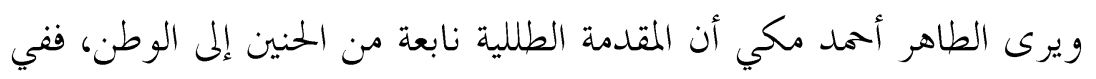

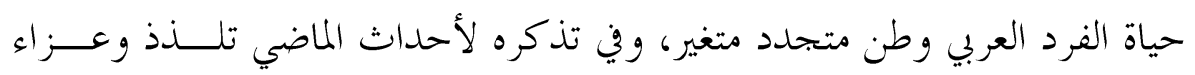

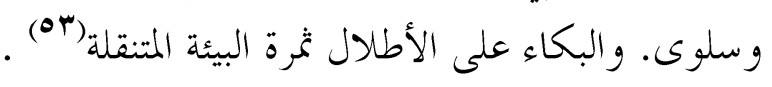

\section{(ه) مقدمة وصف الطبيعة (ه)}

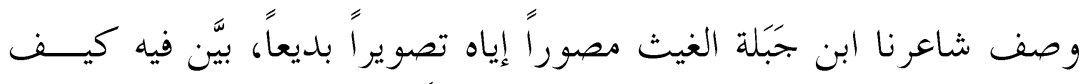

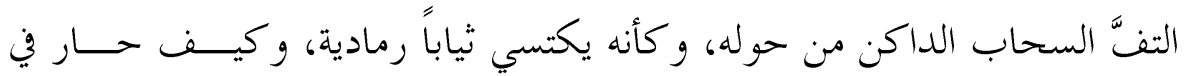

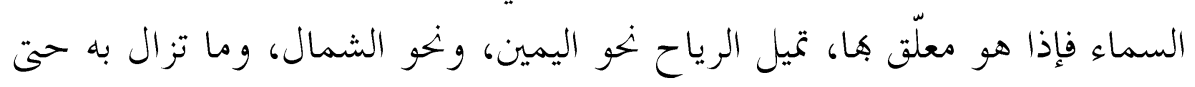

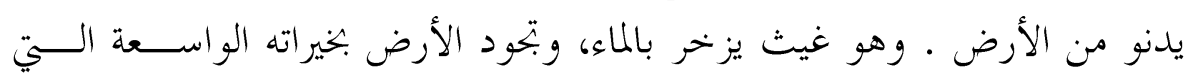

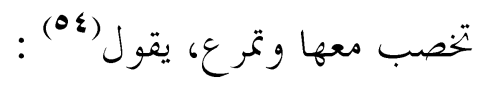




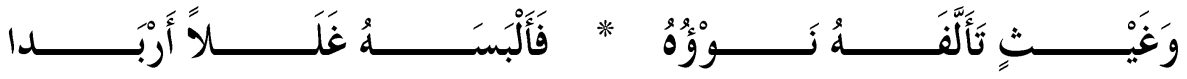

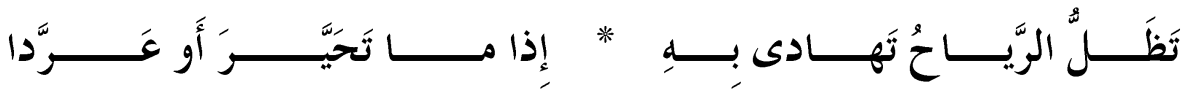

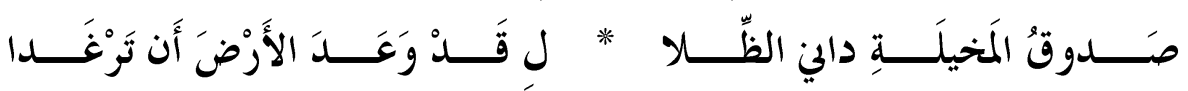
أجل، أكثر الشعراء من وصف الطبيعة في مستهل قصائدهم متحر كة تــارة

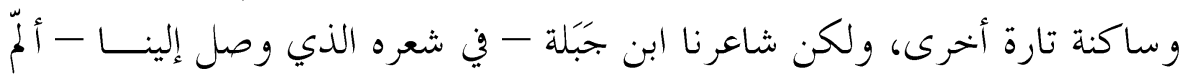

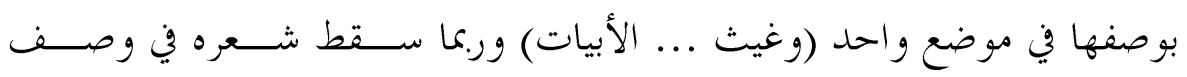

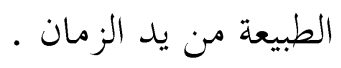

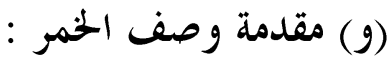

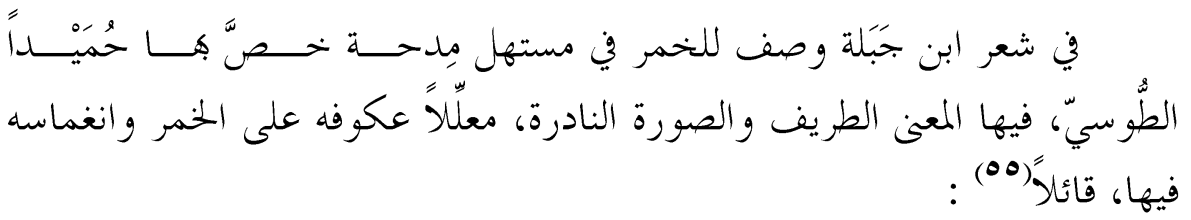

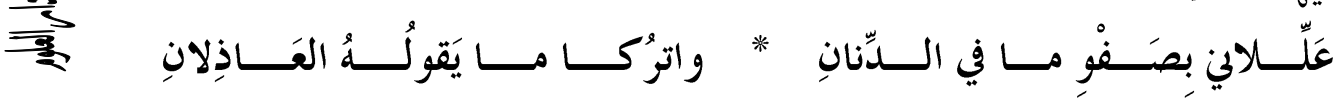

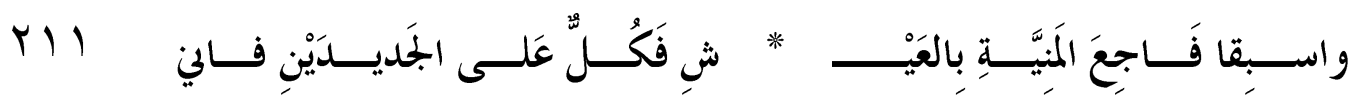

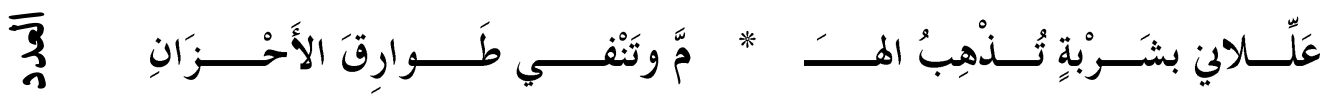

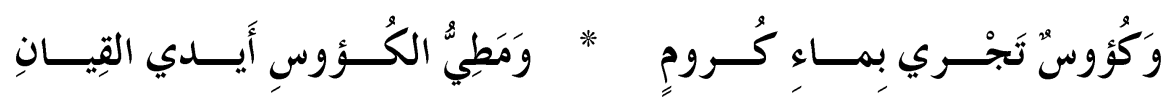

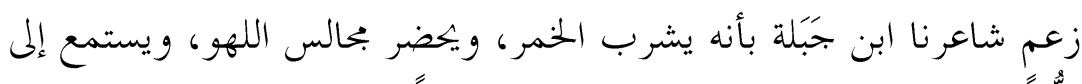

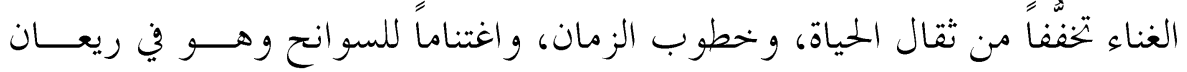

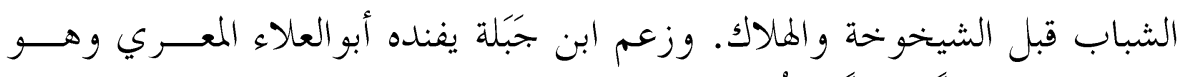

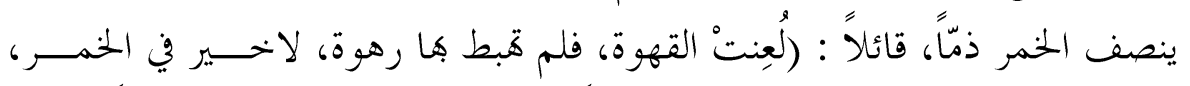

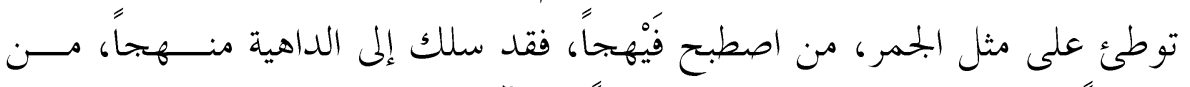

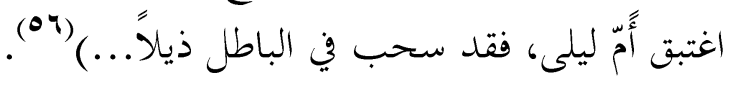

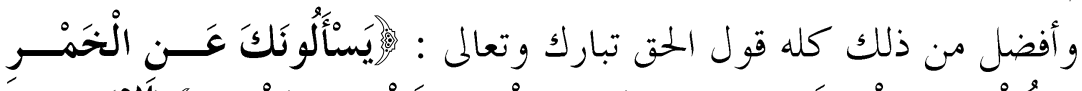

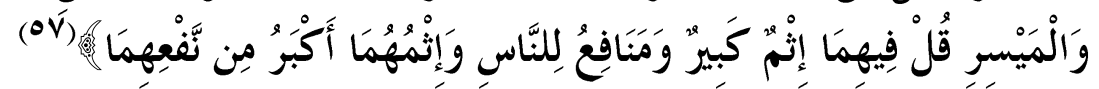
آرَاء النقاد الأقدمينَ في المقدمات 
في مصادر النقد القديم فصول كثيرة، طويلة وقصيرة، تحدث فيها الأقدمون

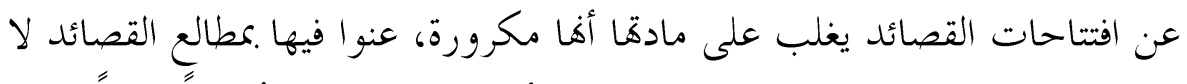

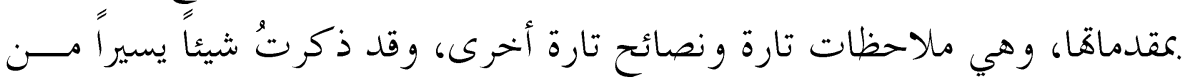

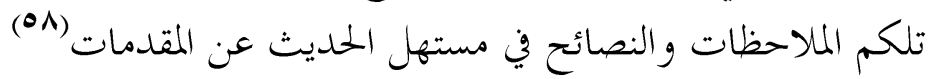

$$
\begin{aligned}
& \text { آراء النقاد الخدثين في المقدمات : }
\end{aligned}
$$

كلف النقاد المحدثون من العرب والمستشرقين بدراسة ظاهرة المقــــدمات في

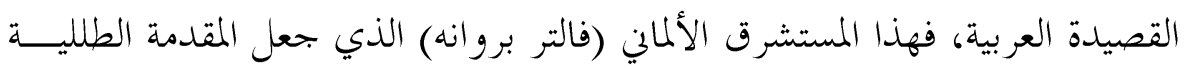

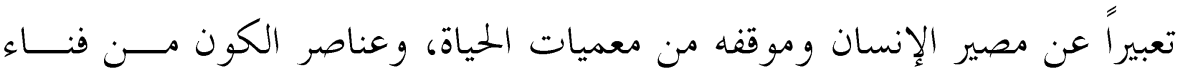

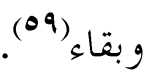

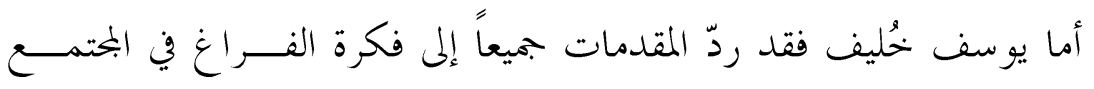

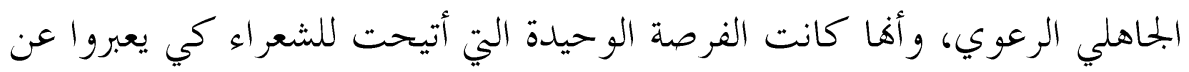

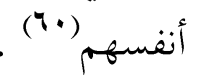

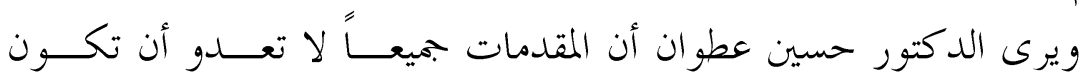

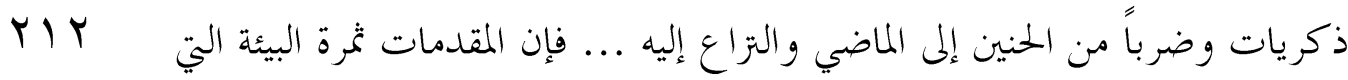

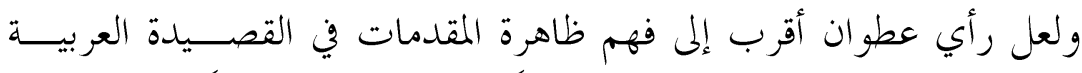

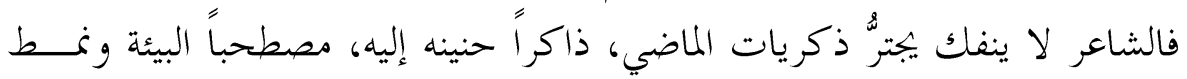
حياها . إنّ المقدمات قديمها وجديدها كانت تقليداً استغله الشعراء لتصوير حياهم

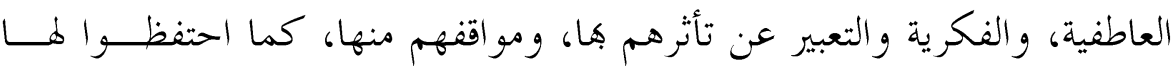

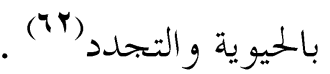

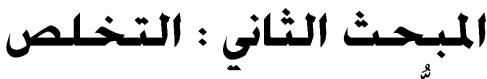

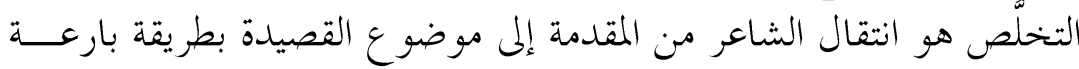

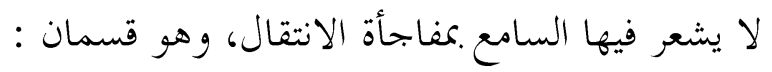

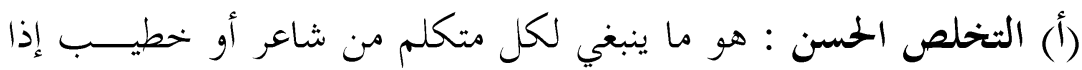

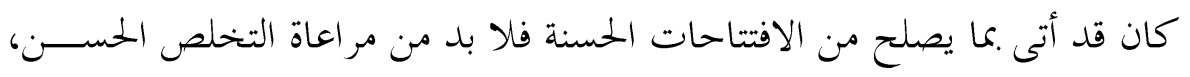


لأنه لا بد له من تقديم الغزل، أو ذكر الفخر، أو ذكر أطروفة بــأدب، تم يــــــر

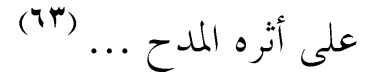

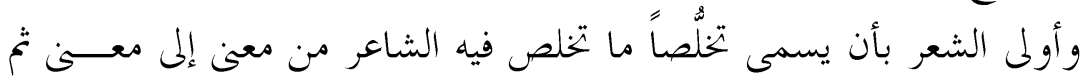

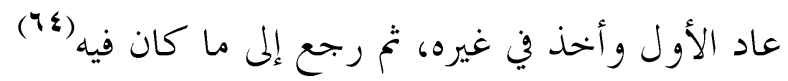

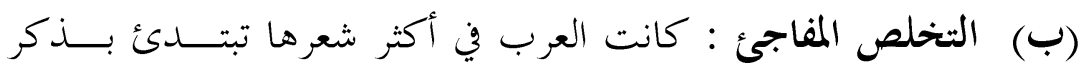

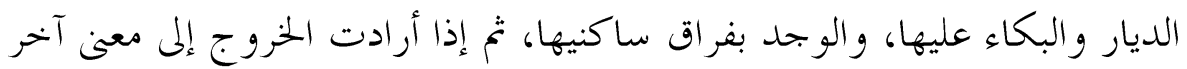

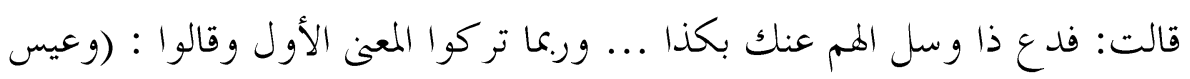

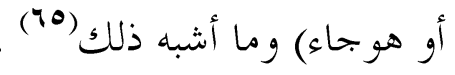
تخلص شاعرنا ابن جَبَلة تخلصاً جيَّداً في بعض قصائده المادحة، مُلمّاً بكــثير

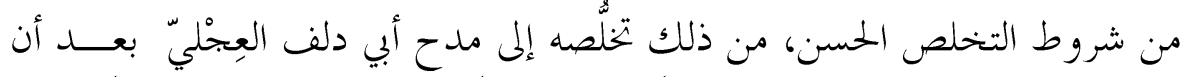

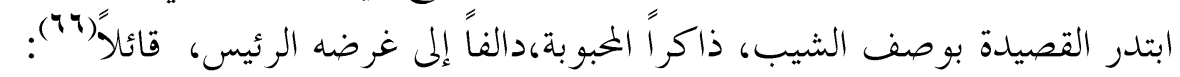

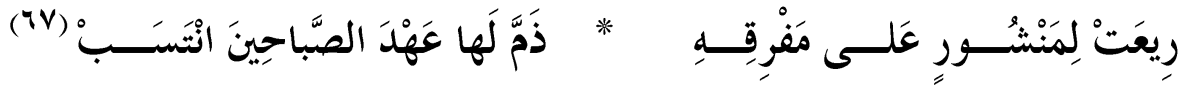

rIT

亨

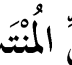

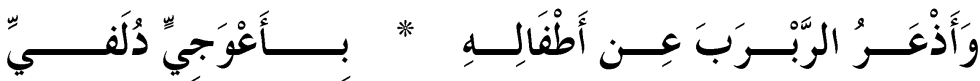

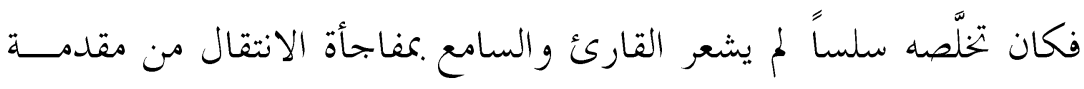
القصيدة إلى موضوعها الرئيس .

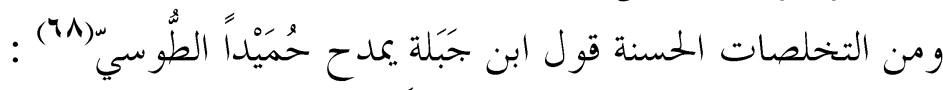
(79) 9

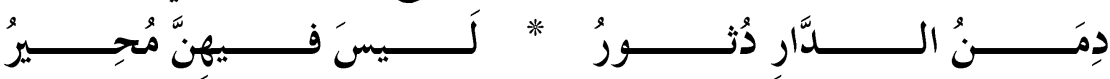

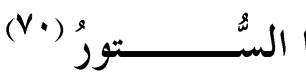
دَتُوارِ الحَّ وَأَزورُ الكاعِ

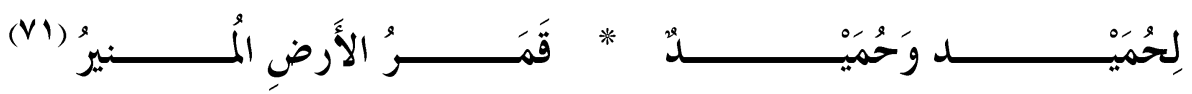

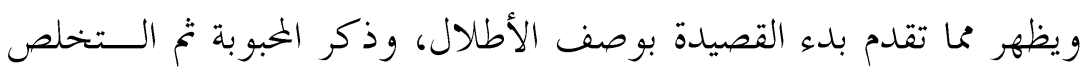

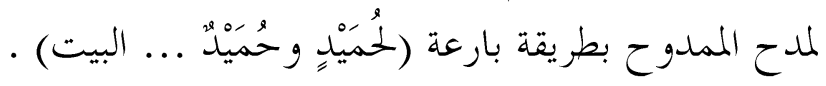


وتمة قصيدة أخرى حظيت بحسن التخلص مدح فيها شاعرنا ابــن جَبَلـــة

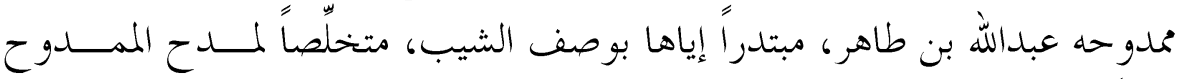
قائلاً (VT)

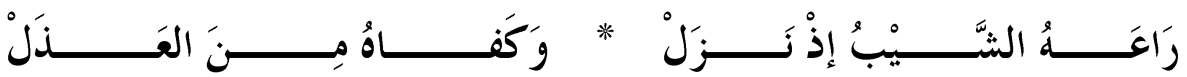

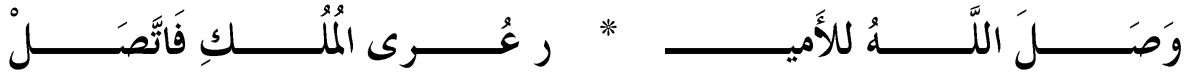

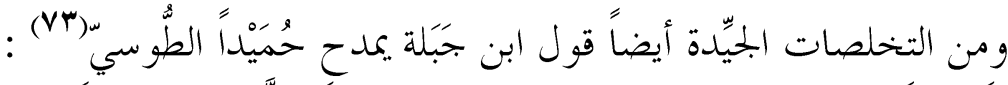

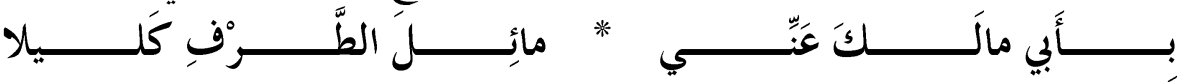

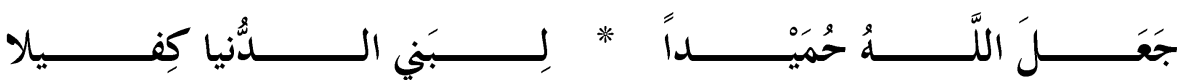

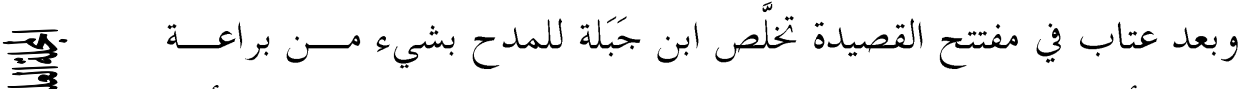

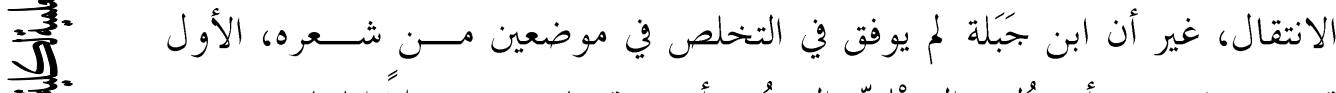

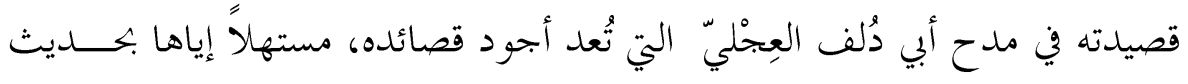

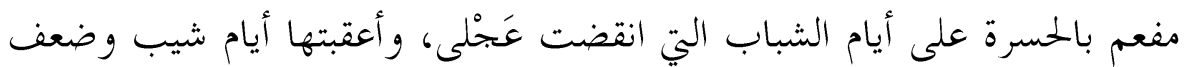

YIs وهرم، قائلاً (V)

$\overline{3}$
2
2

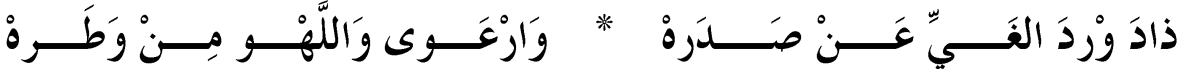

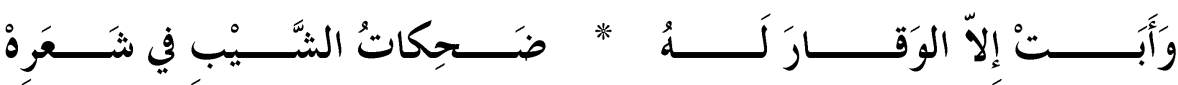

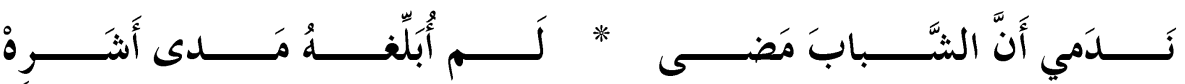

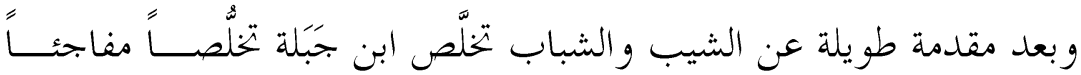

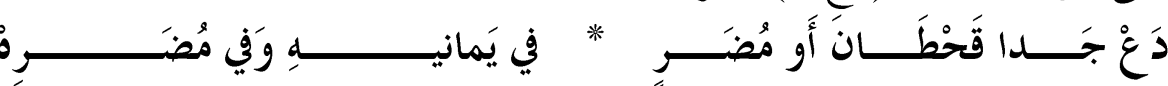

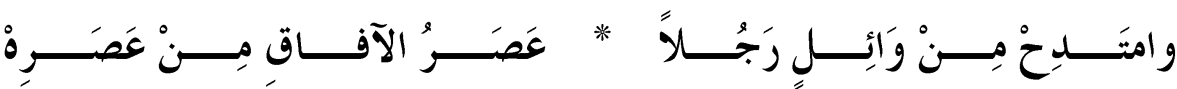

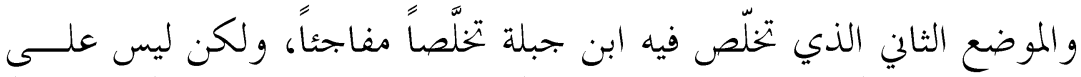

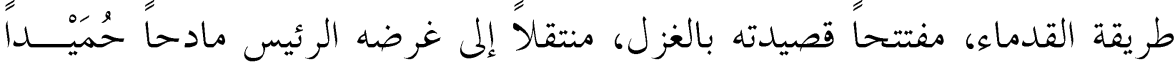

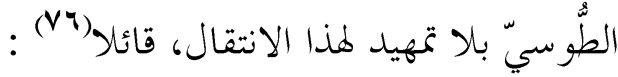

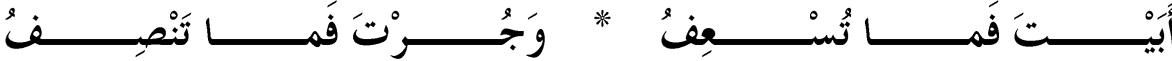




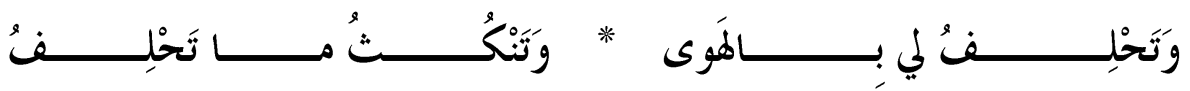

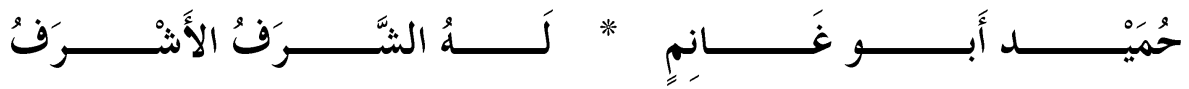

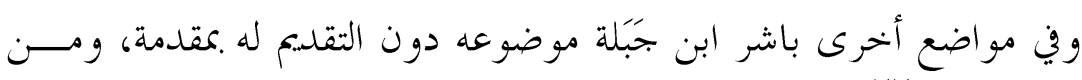

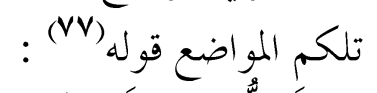

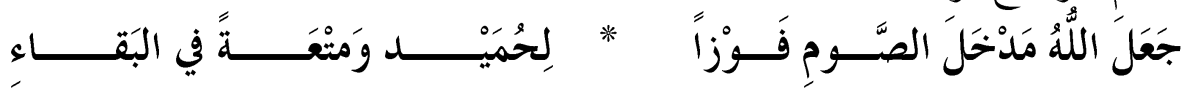

$$
\text { وقوله }
$$

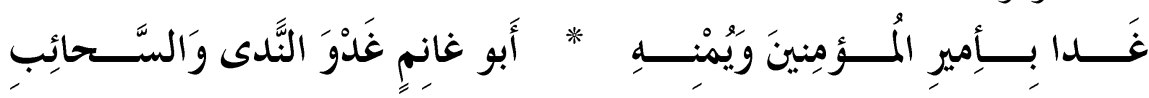

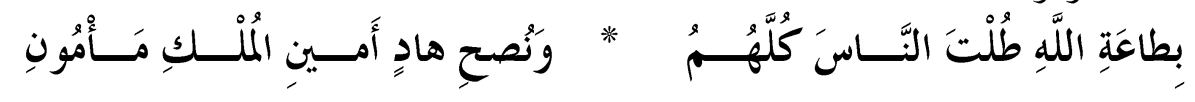

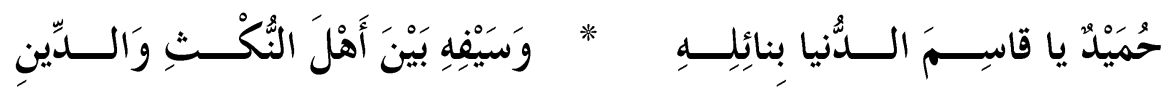

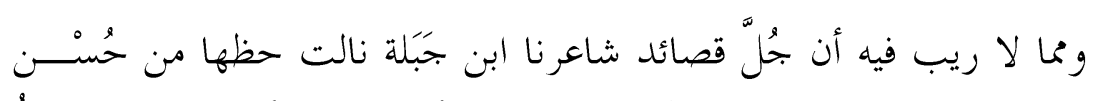

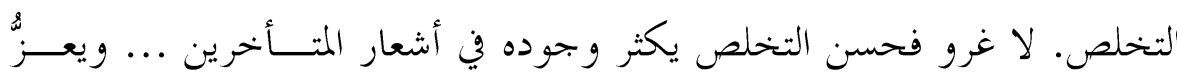
rio

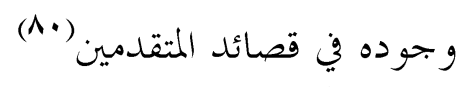
تقدمهم (1)

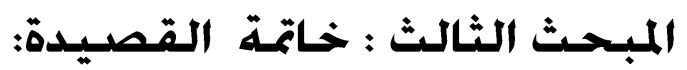

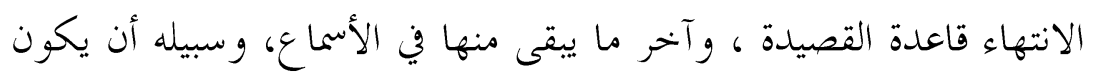

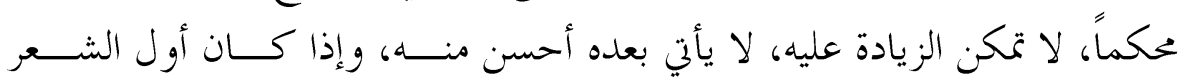

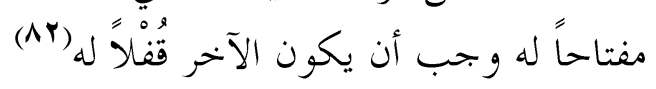
وينبغي لكل بليغ أن يختم كلامه في أي مقصد كان الاخر فأ فأحسن الخواتيم، فإنها

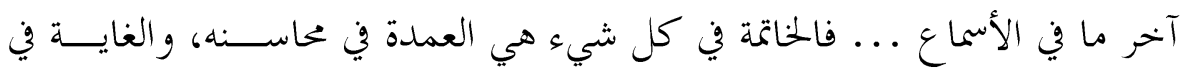
كماله

وبعد حديث النقاد الأقدمين عن خاتمة القصيدة وشروط جودها، حقيق بي

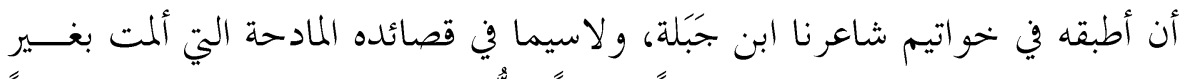

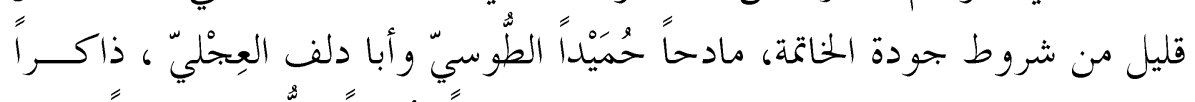

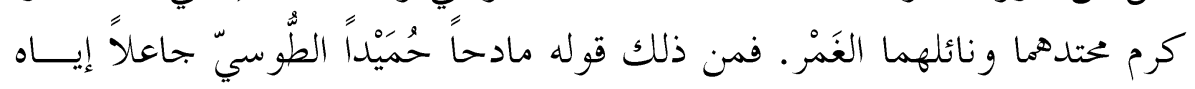




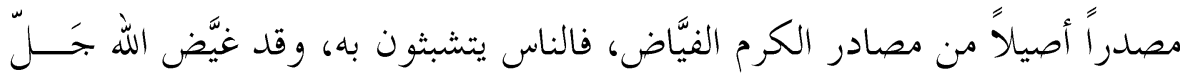

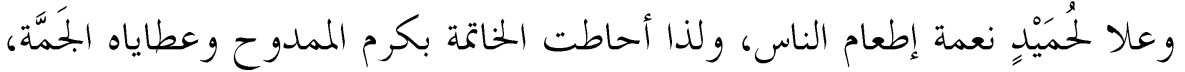

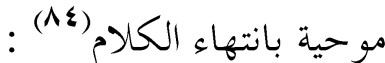

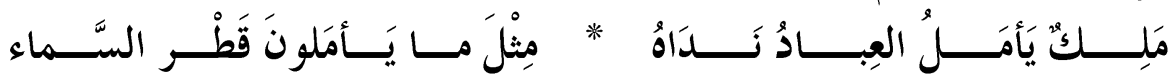

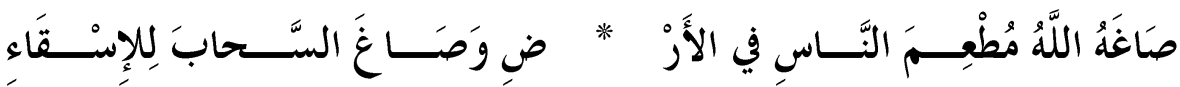

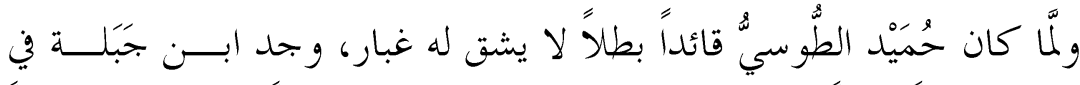

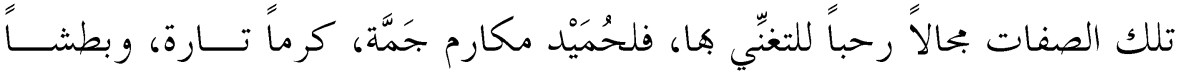

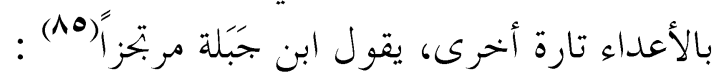

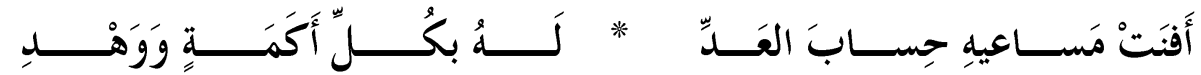

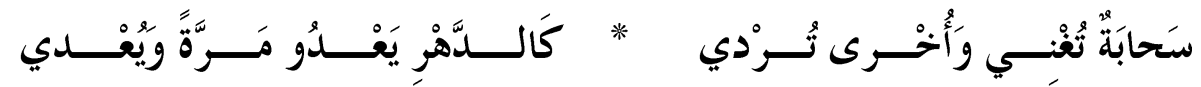

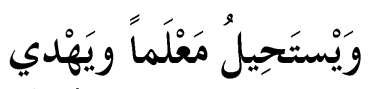

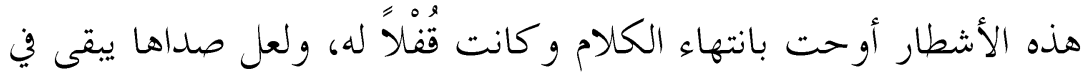

YIT

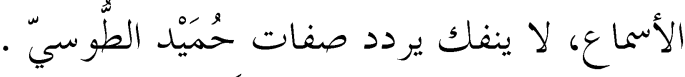

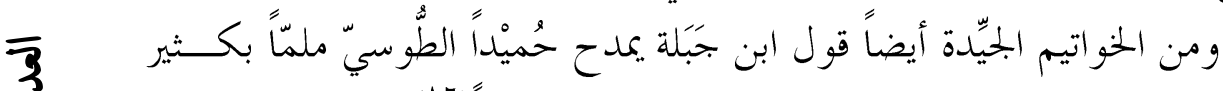

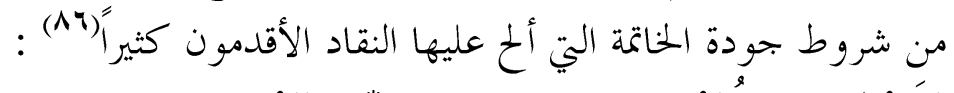
وَتَبُْْ

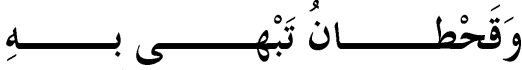

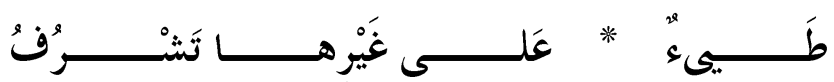

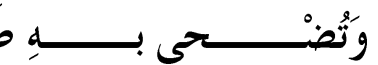
وقوله أيضاً (AV) :

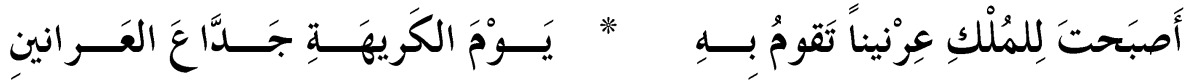

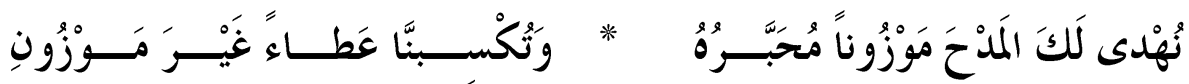
ففي الخاتمتين آنفتيْ الذكر صفات مدح جمَّة، فحُمَيْد رمز الفخار والسؤدد

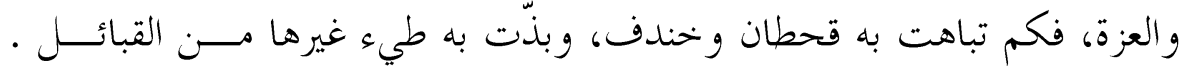

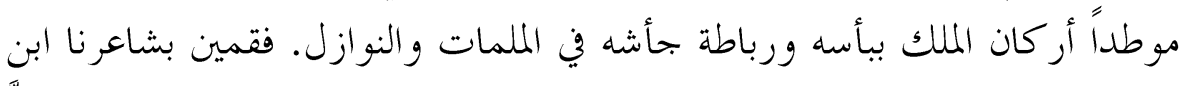

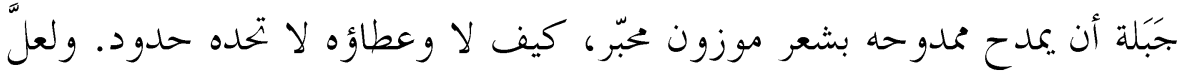


الخاتمتين جمعتا كثيراً من شروط الجهودة؛ لأكما حوتا حسن المعنى، وصفاء اللفــــا،

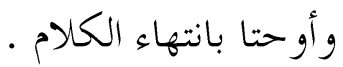

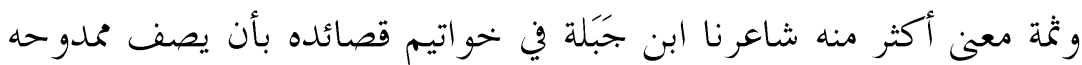

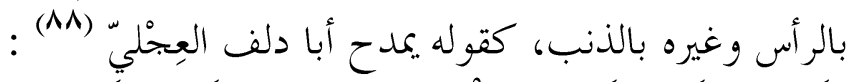

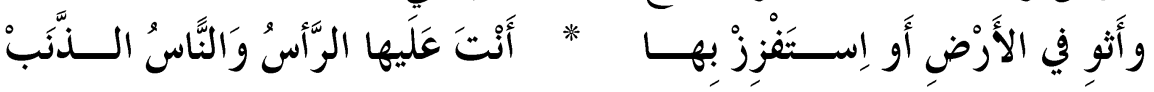

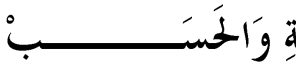

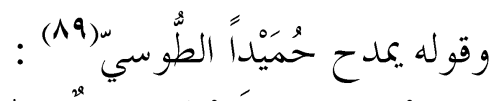

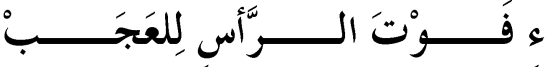
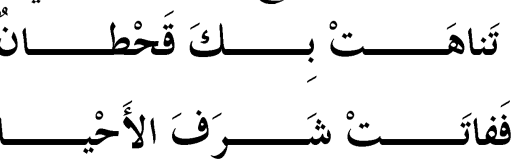

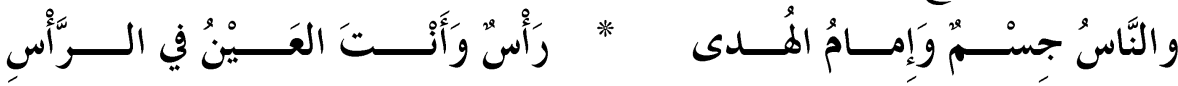

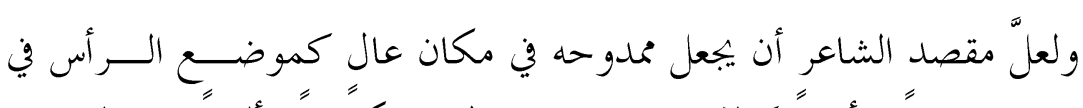

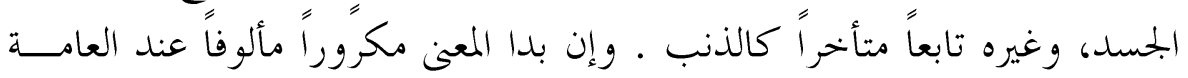

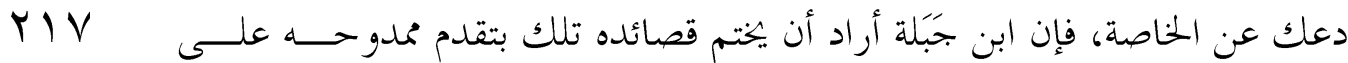

ختمب شاعرنا ابن جَبَلة بعضاً من قصائده، داعياً لممدو حيه أبي دلف العِجْليِّ

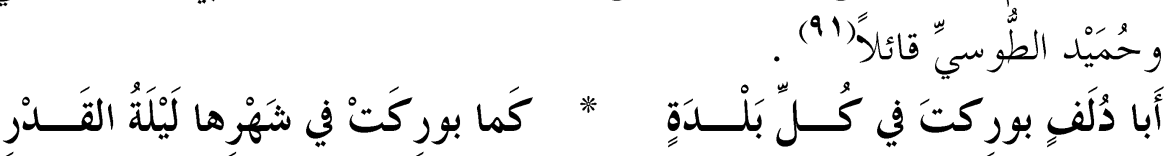

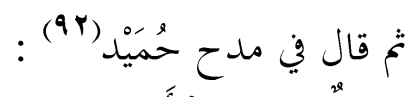

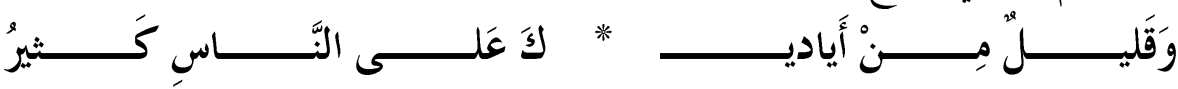

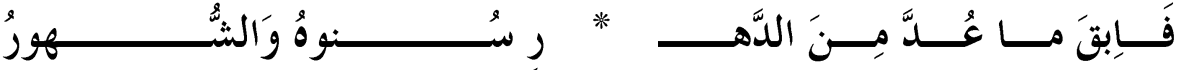

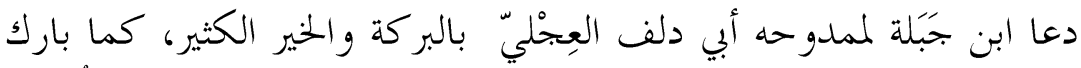

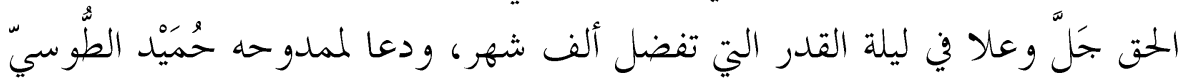
بالبقاء حيّاً على مر الدهور في ليلة الفدر التيّ تفعن

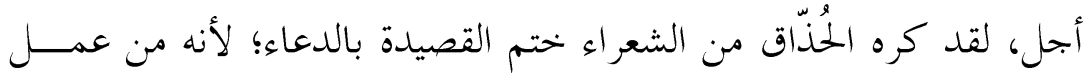

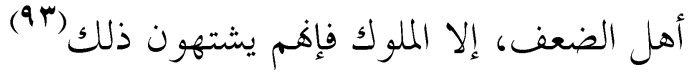




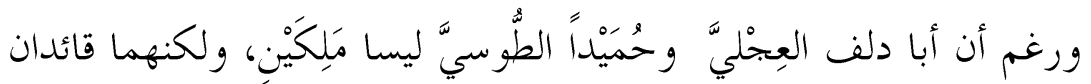

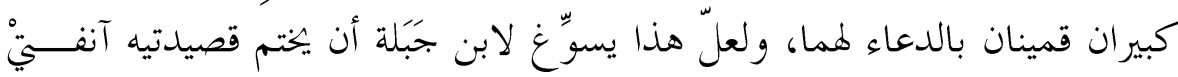

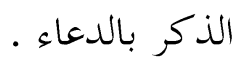

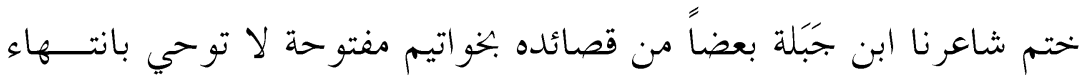

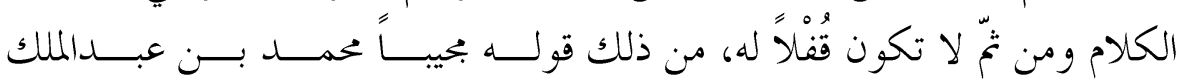

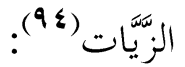

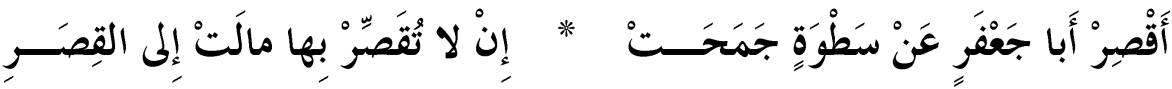

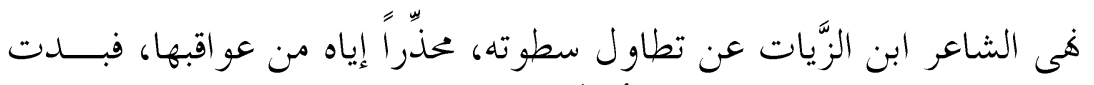

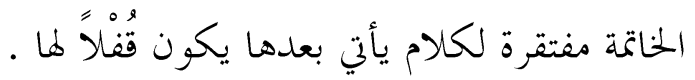

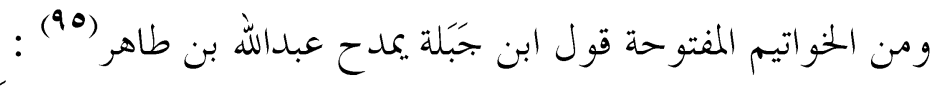

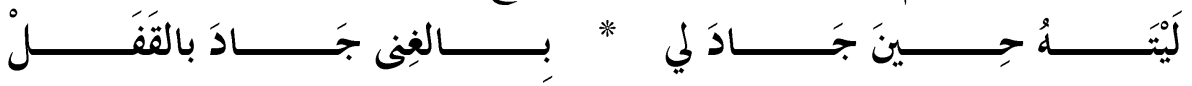
فالخاتمة تبدو مفتوحة، و النفس راغبة في إتمام الشاعر لذلك الــتمتي بعـــودة

Y)

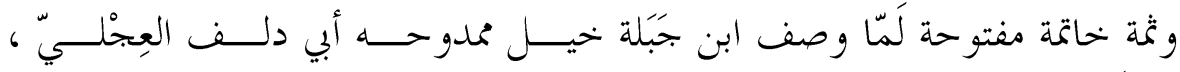
الممدو ح إليه .

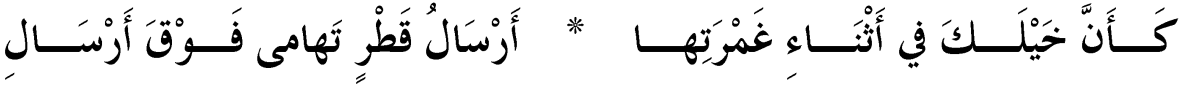
يَخْرُجَنَ مِنْ غَمَرَ اتِ المَوْتَِ ســامِيَةً

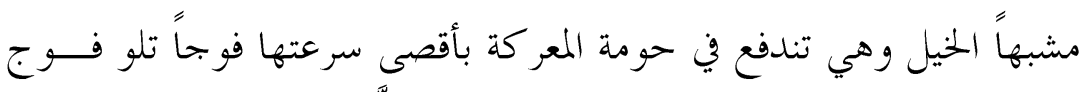

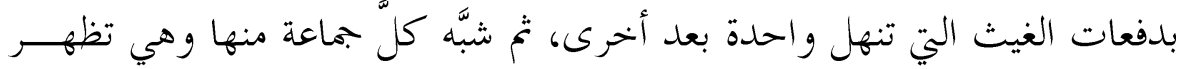

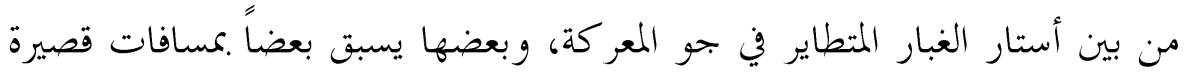

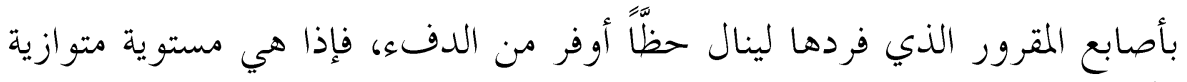

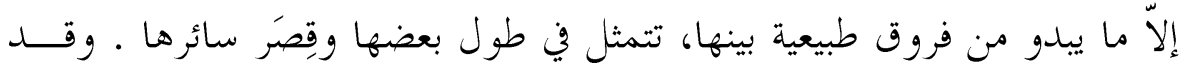

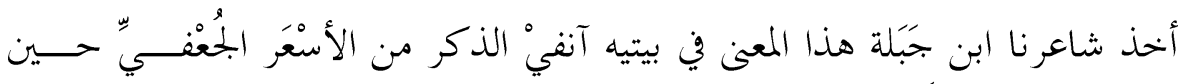
وصف الخيل قائلاً :

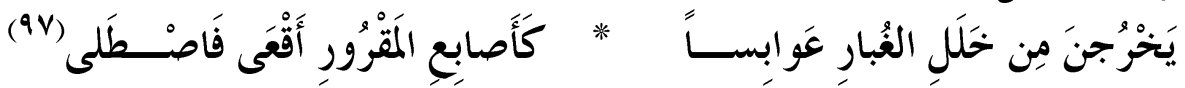


ورغم جودة التشبيه في بيتيّ ابن جَبَلة، لكنَّ الخاتمة لم توح بانتهاء الكــلام

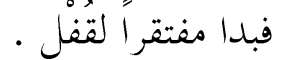

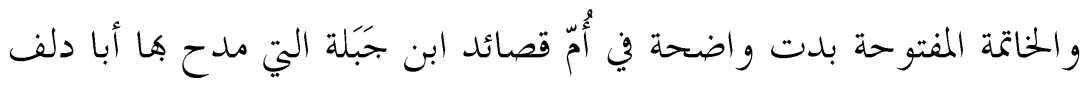

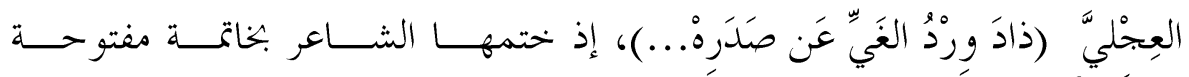

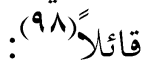

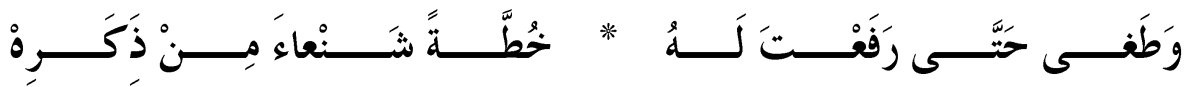

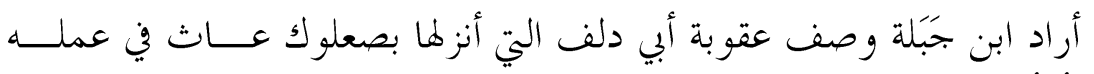

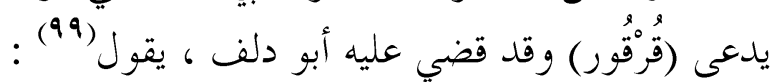

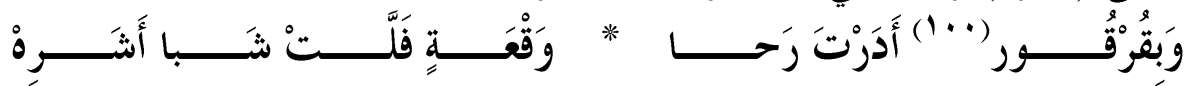

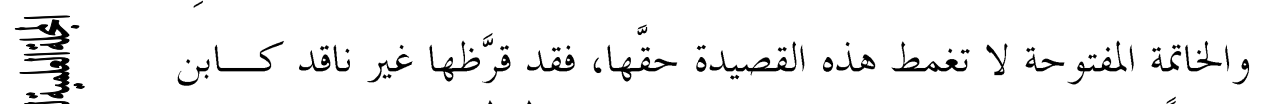

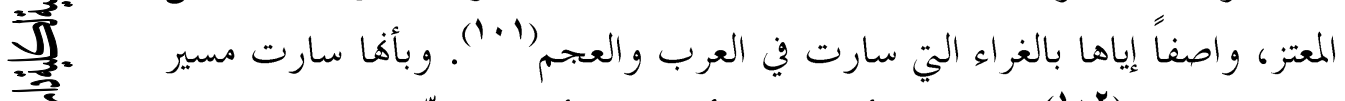

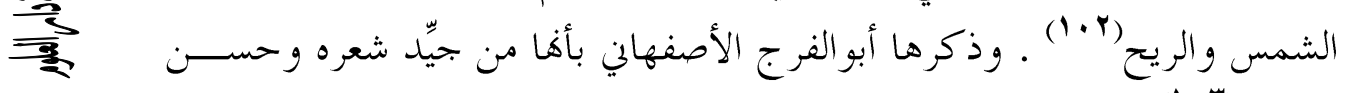

r 9

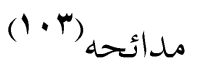

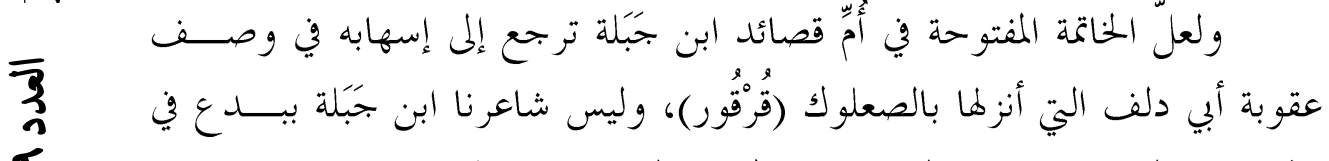

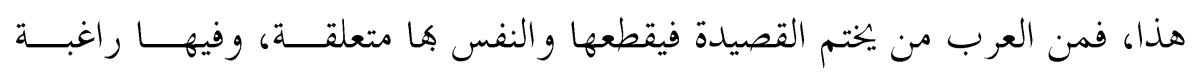

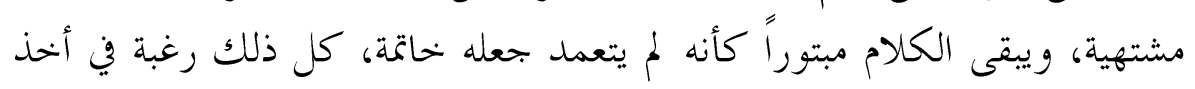

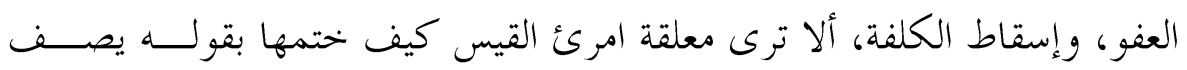

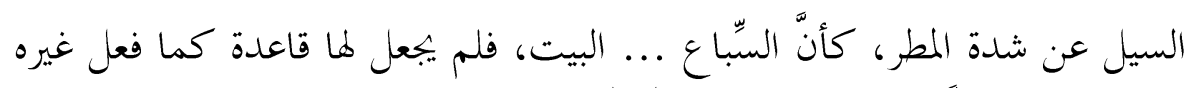

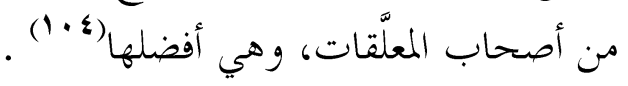

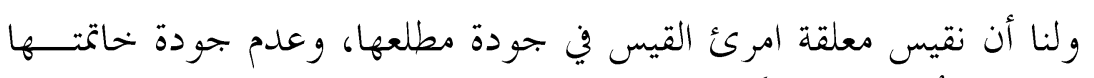

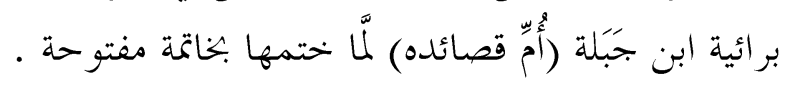

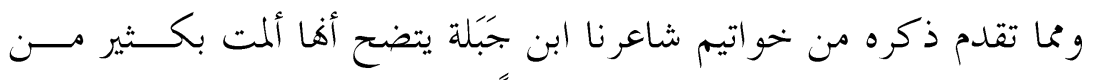

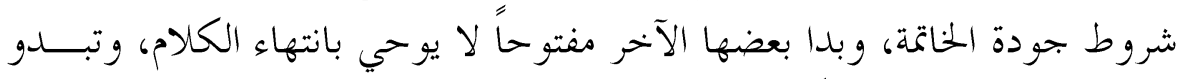

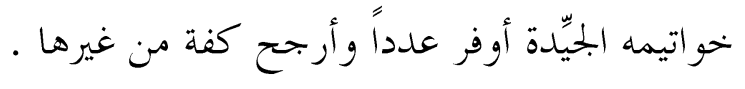




\section{المبـحث الرابع : وحدة القصسيدة:}

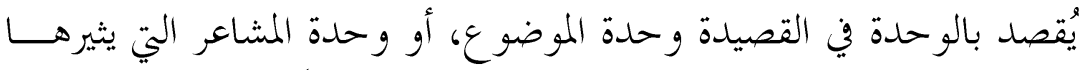

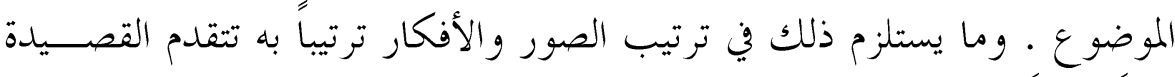

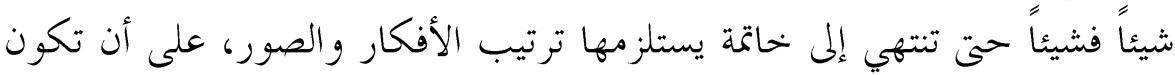

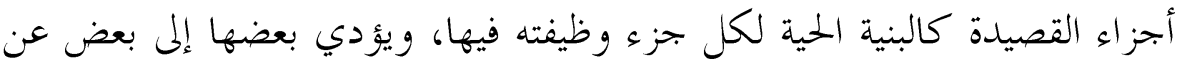

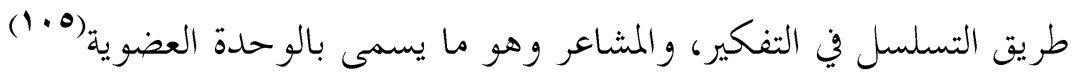

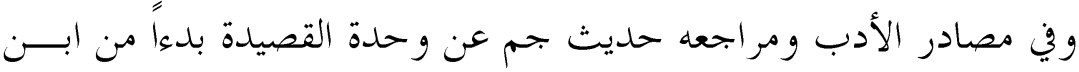

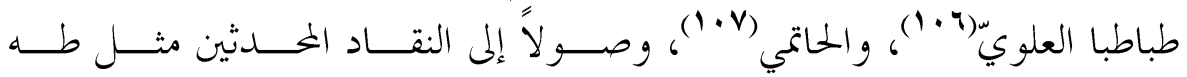

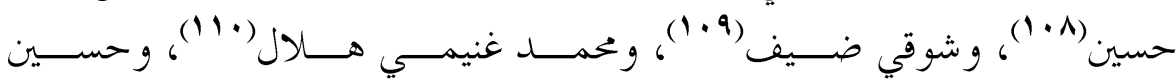
عطو ان (111)

أما وحدة القصيدة عند شاعرنا ابن جَبَلة فتوجد في قصيدة واحدة رثى هـا

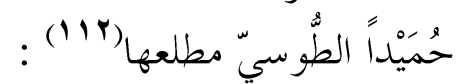

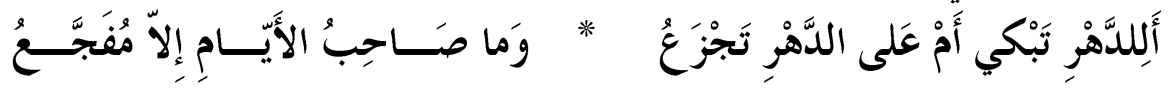

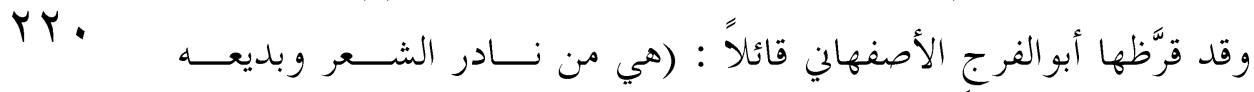

ב

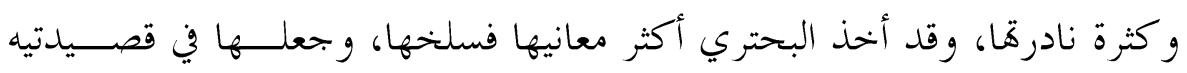

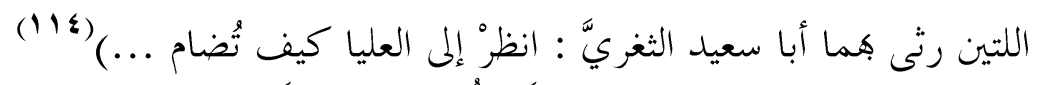

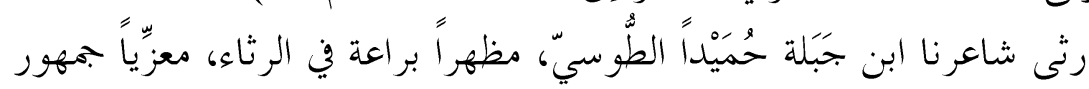

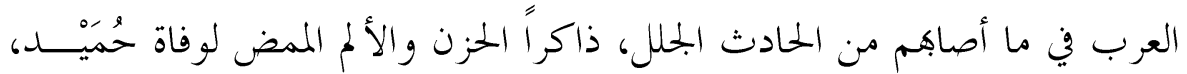

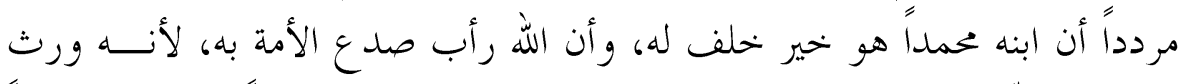

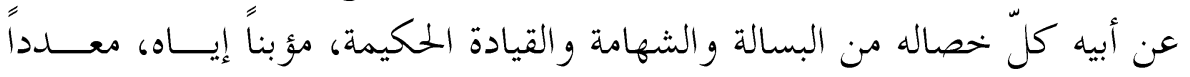

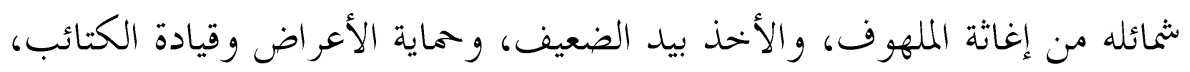

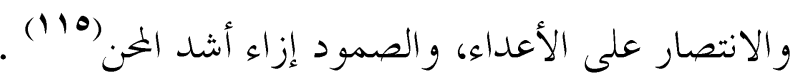

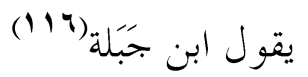

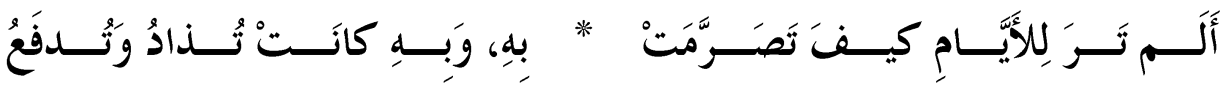

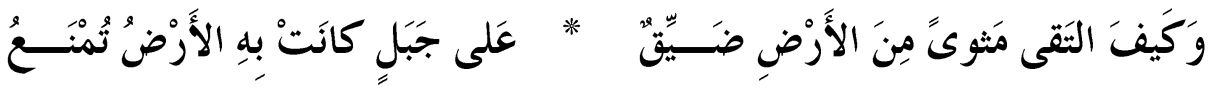




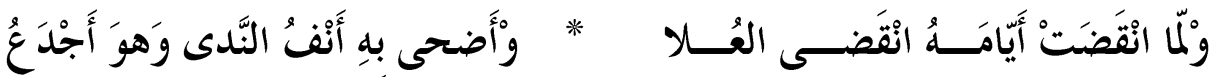

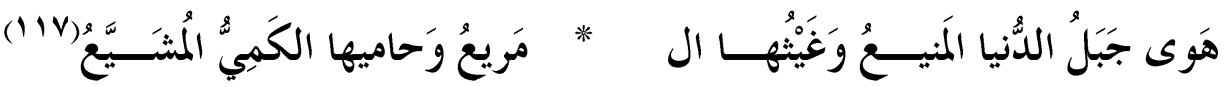

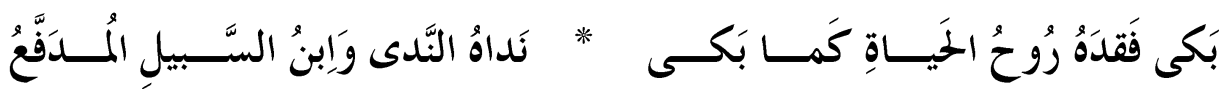

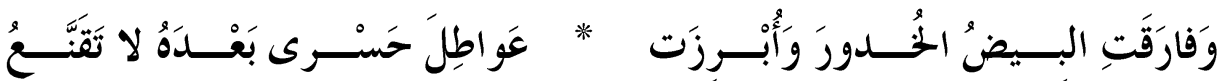

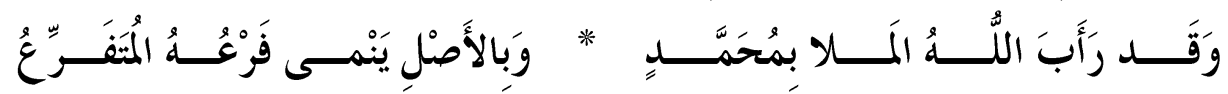

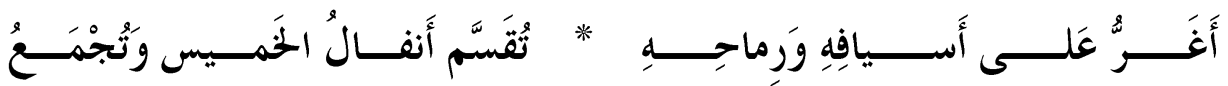

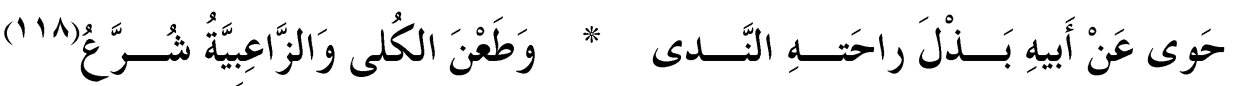
في القصيدة وحدة شعور حزين من مفتتحها إلى خاتمتها؛ لأها لم تخرجا

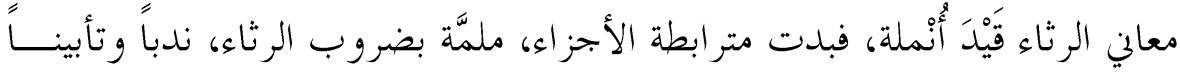

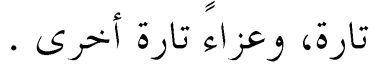

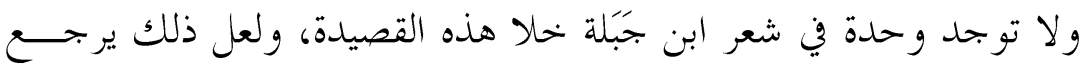

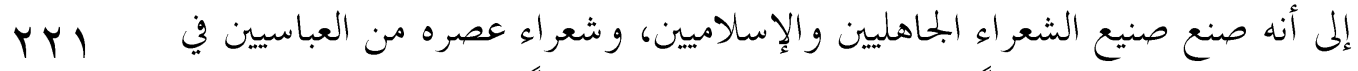

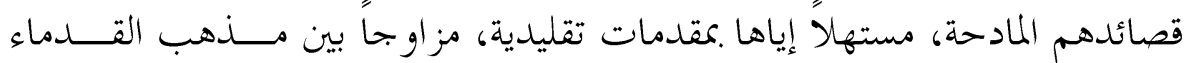

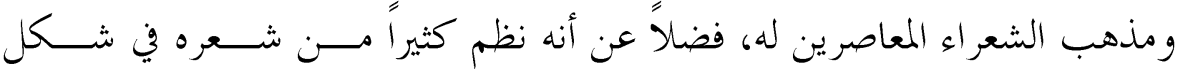

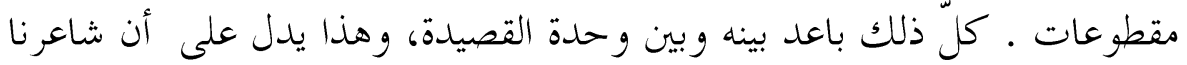

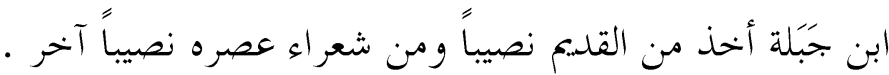

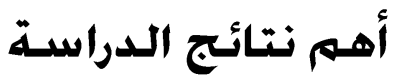

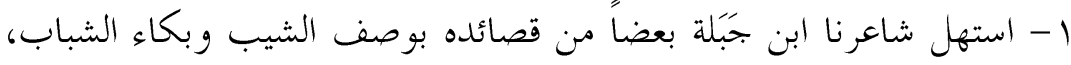

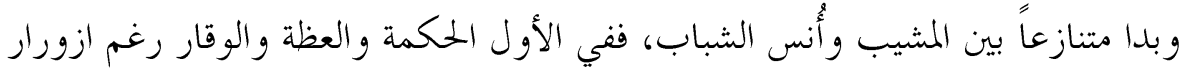

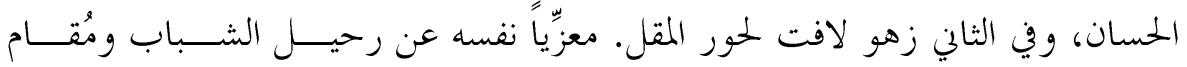

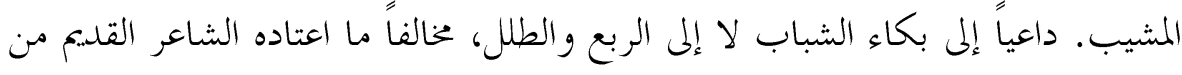

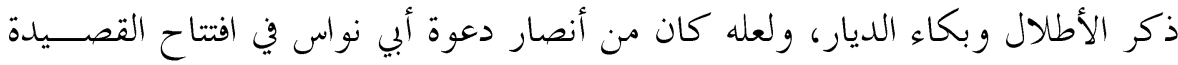

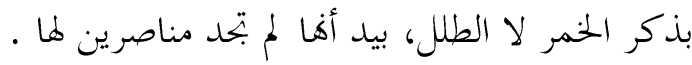

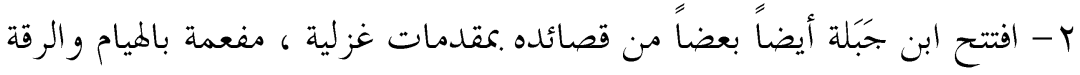

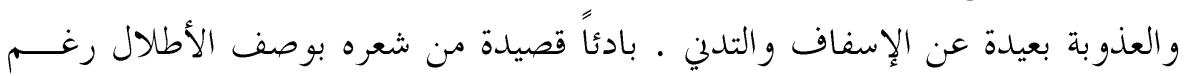


مناداته بتر كها - دون إكثار من حشد الرسوم البدوية، ولعل المقدمة كانت تقليداً فنيّاً

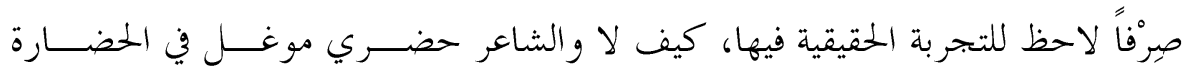

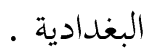

ب- مال ابن جَبَلة في مقدمة الاعتذار والعتاب إلى الحجاج و المنطق مســتلهماً

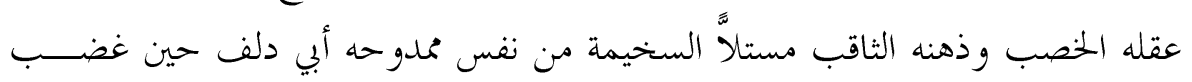

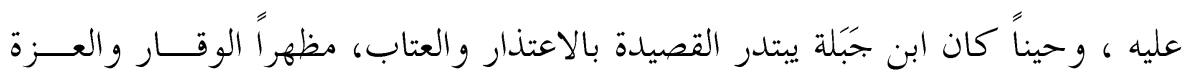
والكر امة مع أعظم رجال الدولة ذاكراً صبره ورباطة جأشه، مهلداً بالقطيعة والجفوة.

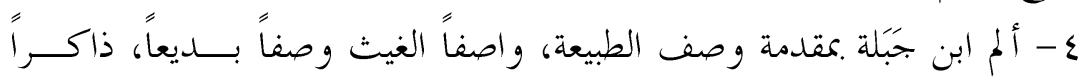

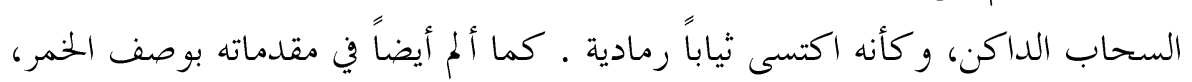

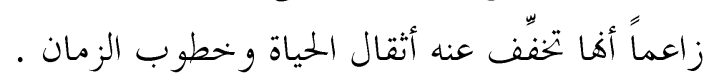

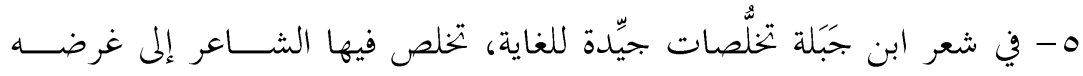

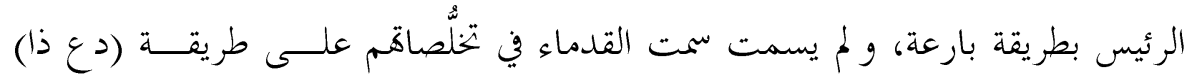

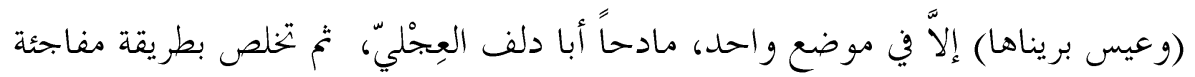

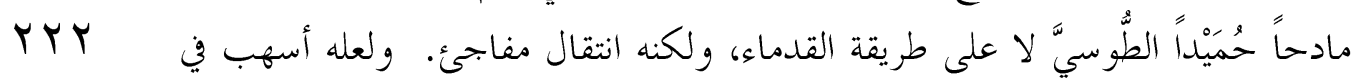

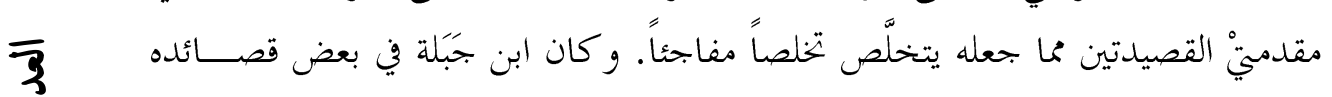
يباشر موضوعه دون مقدمات

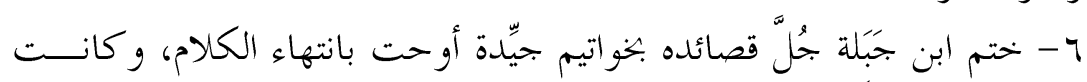

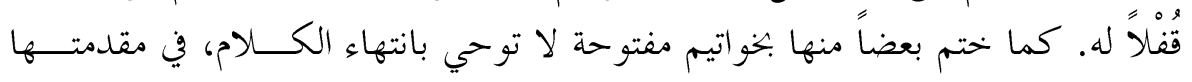
خاتمة قصيدته الرائية (وطغى حتى رفعت له ....) و ختم قصيدتين بخاتتين تضمنتا الدعاء

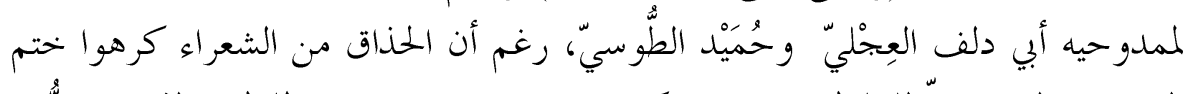

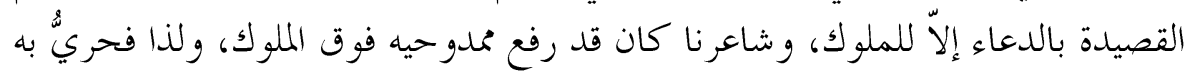
أن يلعو لهما.

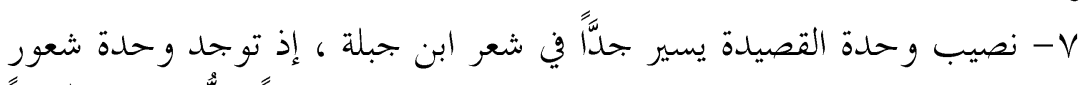

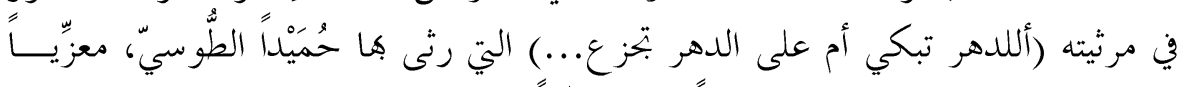

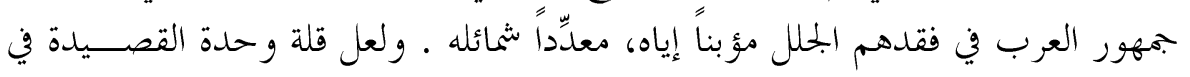

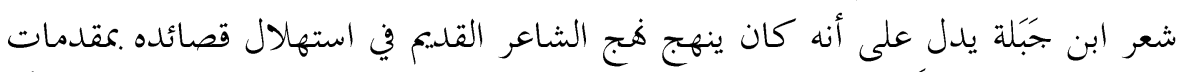

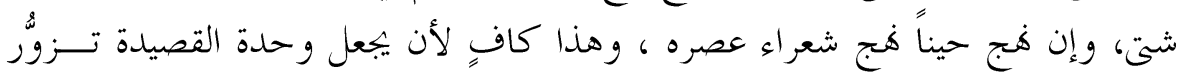




\section{ثبت المصسادر والمراجـ}

القر آن الكريم

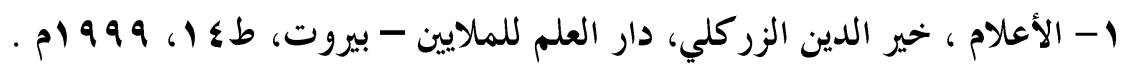

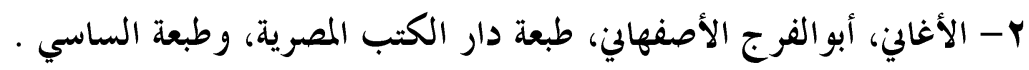

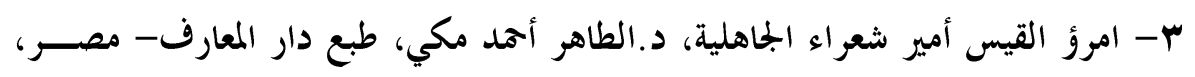

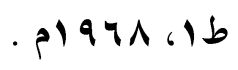

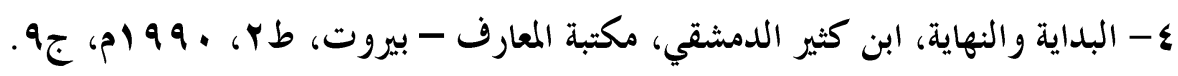

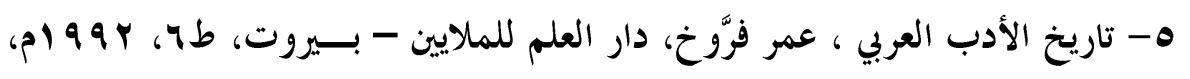

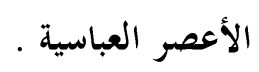

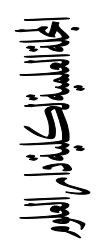

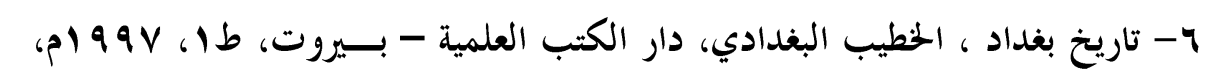

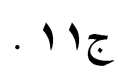

V- تاريخ الطبري، الطبري، دار سويدان - بيروت(د.ت)، ج9 .

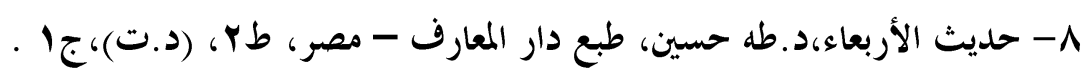

MT

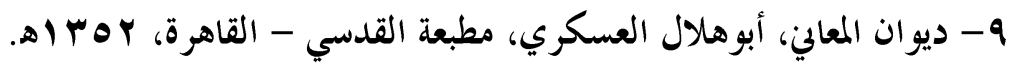

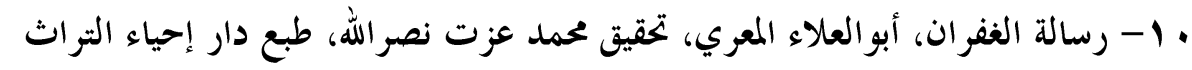

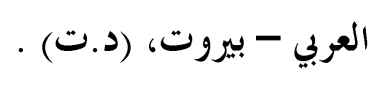

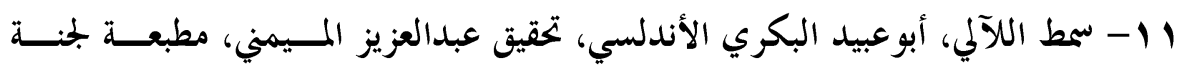

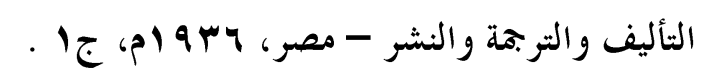

r ا - شذرات الذهب في أخبار من ذهب، ابن العماد الحنبلي، تحقيق مصطفى عبدالقادر

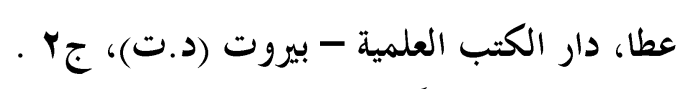

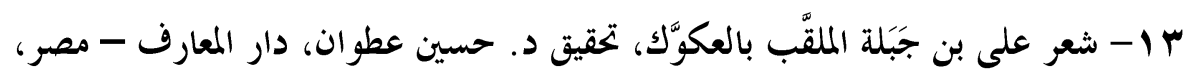

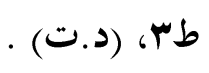

ع ا- الشعر والشعراء، ابن قتيبة، تحقيق أحد محمد شاكر، طبع دار المعارف - مصر، عام

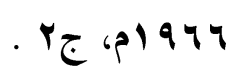




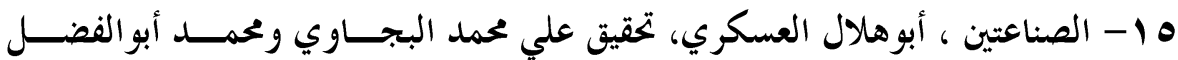

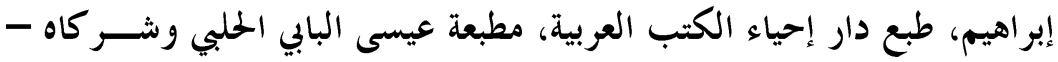

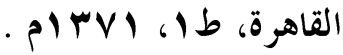

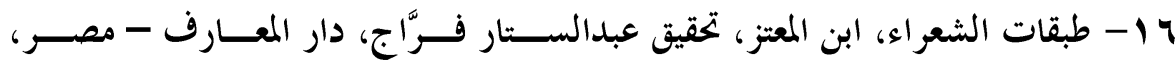
. 1907

IV

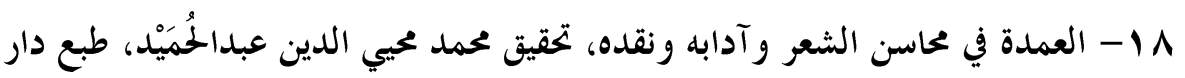

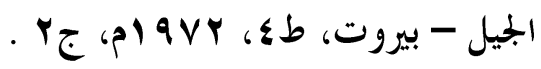

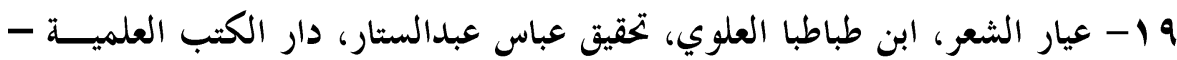

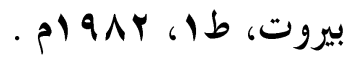

• r- كتاب الطراز المتضمن لأسرار البلاغة وعلوم حقائق الإعجاز، العلوي اليمني، دار

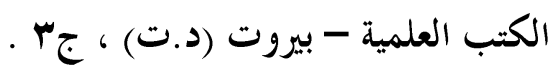

ا Y - مر آة الجنان وعبرة اليقظان في معرفة ما يعتبر من حوادث الزمان، اليافعي، مؤسسة

TYE

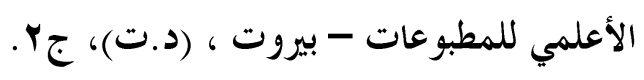

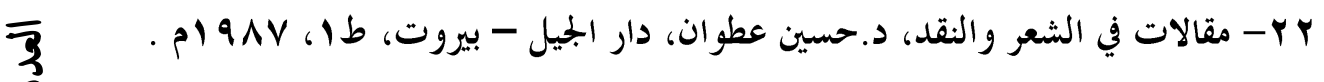

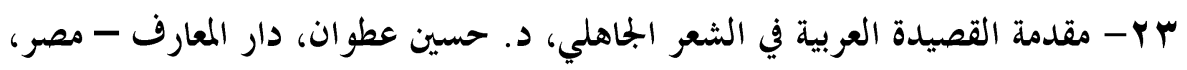
. p) 9 .

צ Y - مقدمة القصيدة العربية في العصر العباسي الثاني، د. حسين عطوان، دار الجيــل -

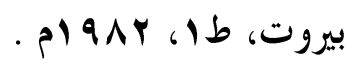

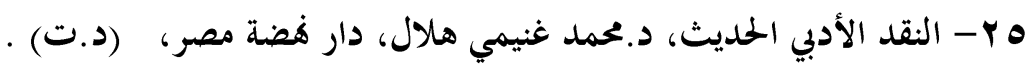

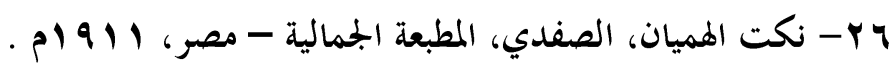

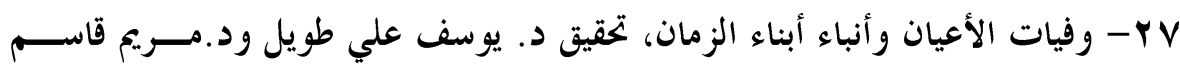

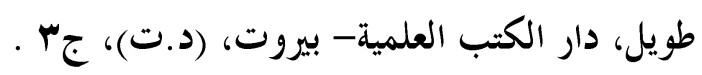




\section{الهوامش والإحسالات :}

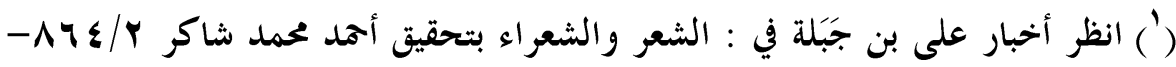

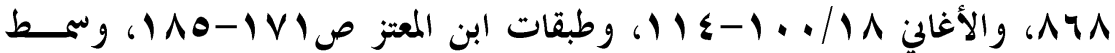

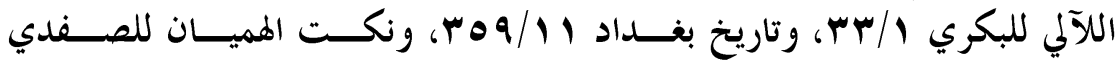

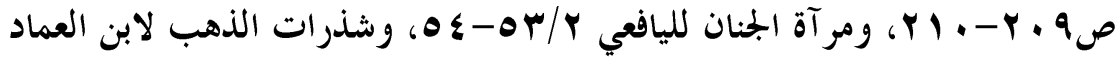

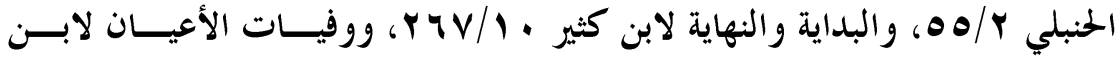
خلكان

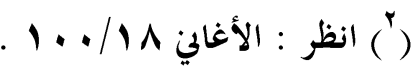

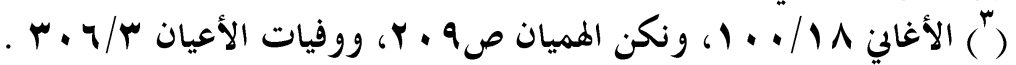

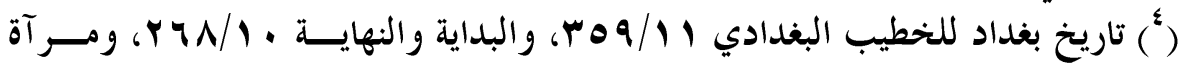
الجنان

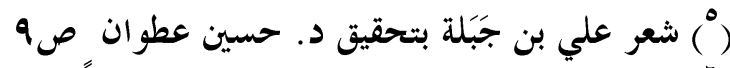

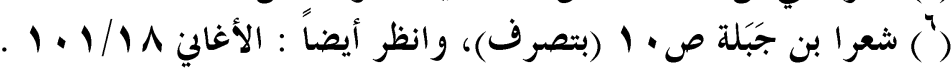

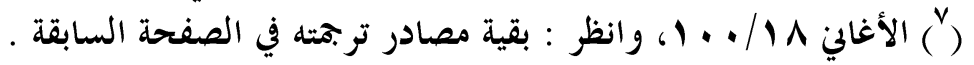

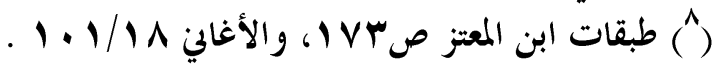

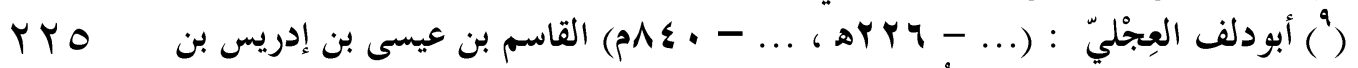

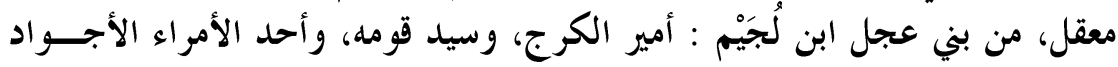

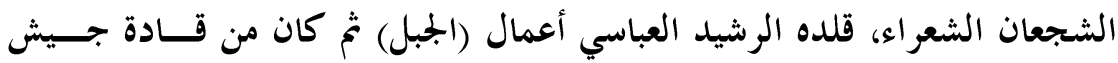

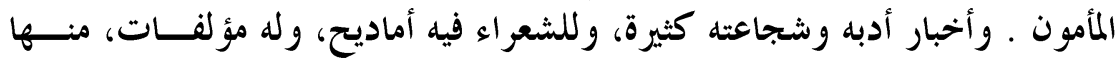

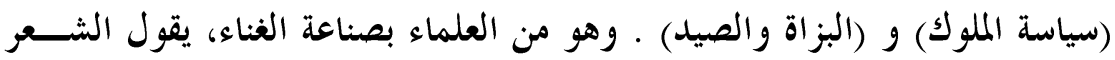

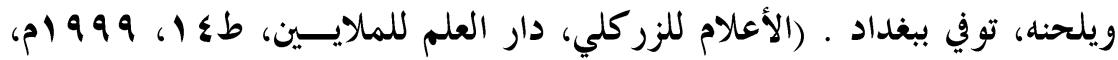

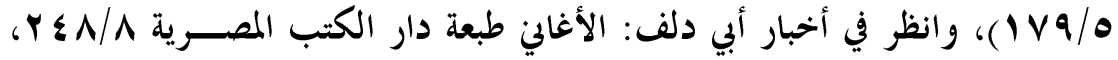

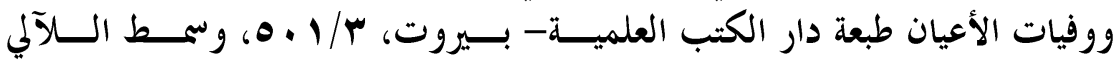

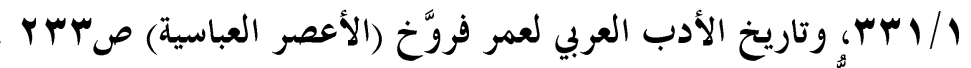

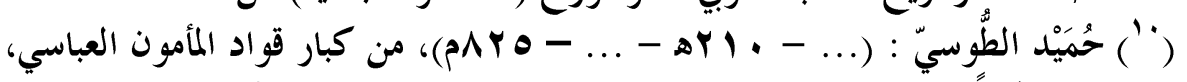

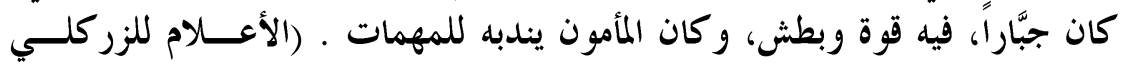
. $(r \wedge r / r$

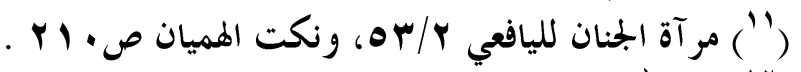

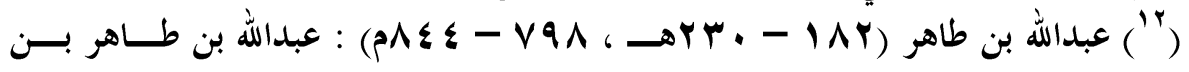

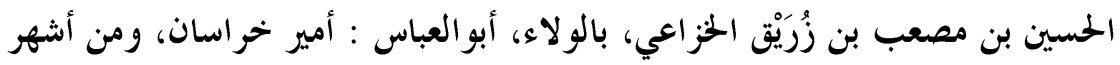

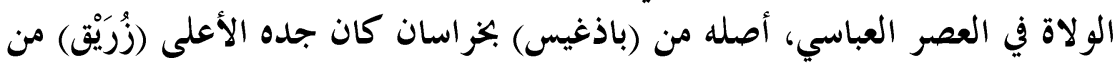

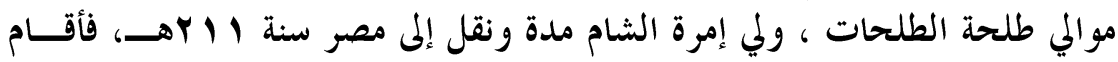


سنة، ونقل إلى الدينور تم و لاه المأمون خر اسان، وظهرت كفاءته، فكانت له طبرستان

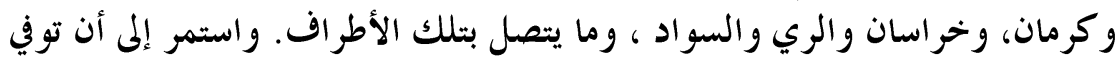

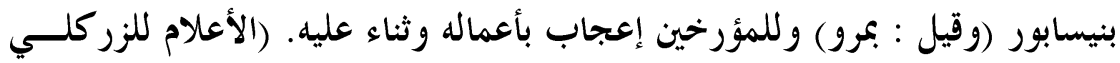

$$
\text { . (9 } 9 \text { - } 9 \mathbf{r} / \varepsilon
$$

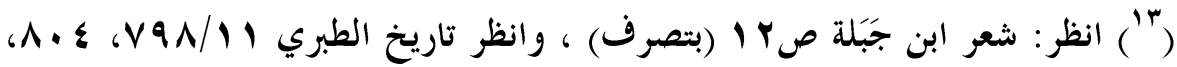
. A ا

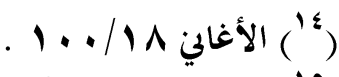

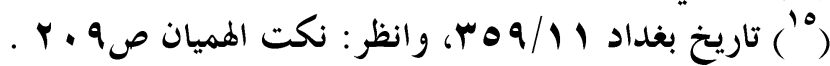
( )

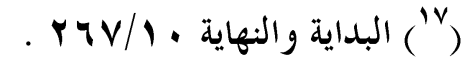
(

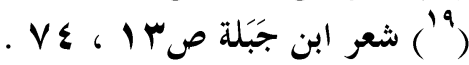

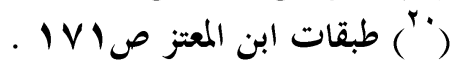

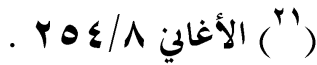
(

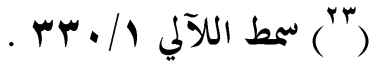

rYY

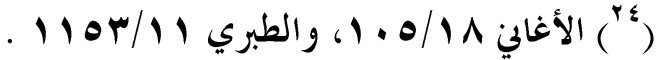

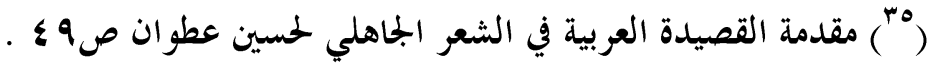

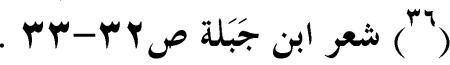


矛-

rrV

$\overline{3}$

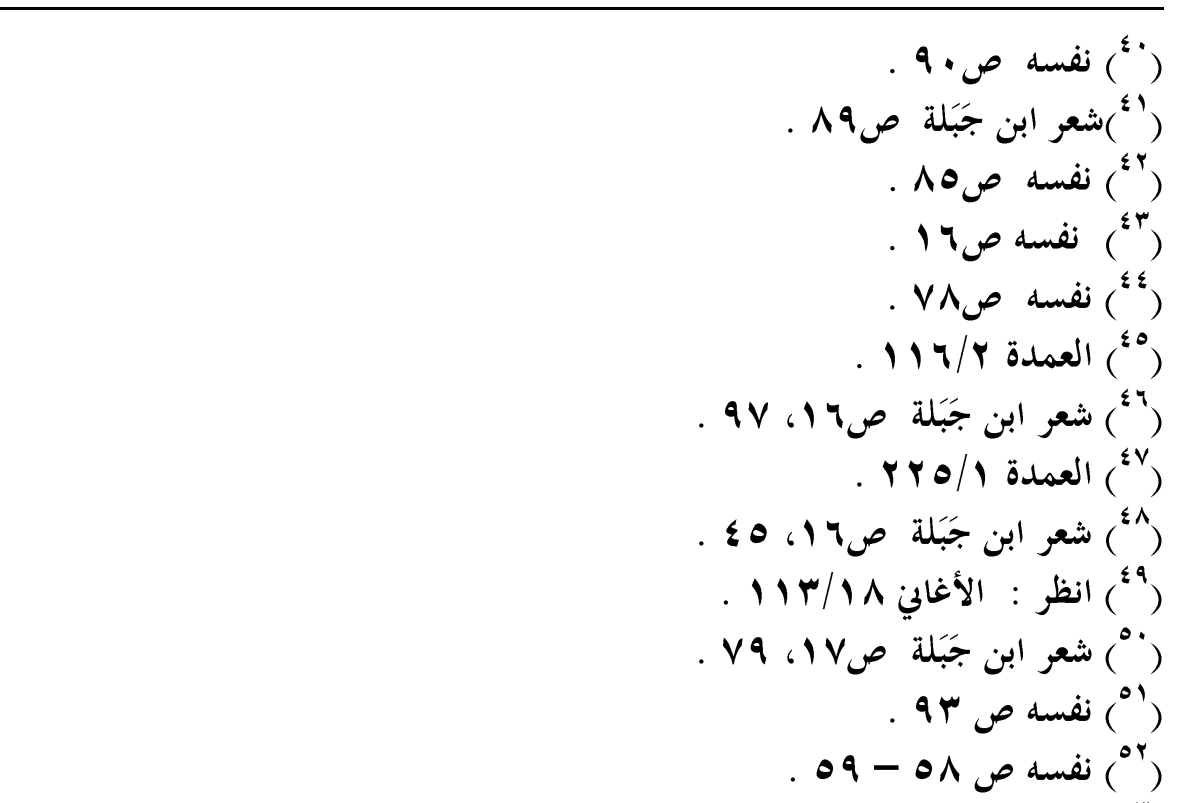

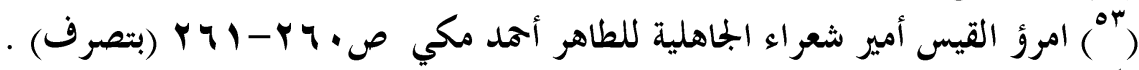
( )

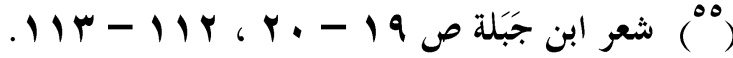

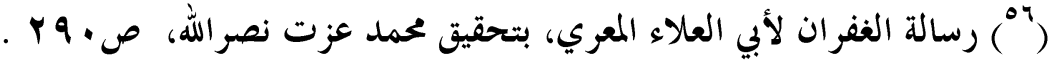

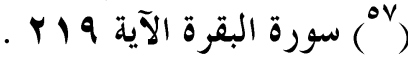

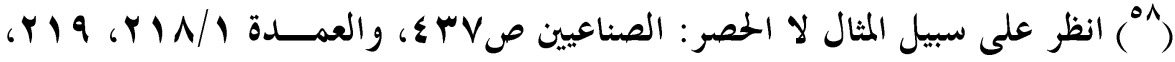

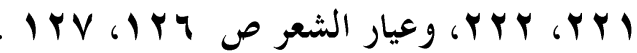

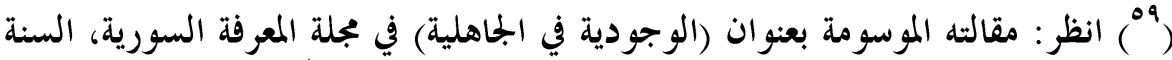

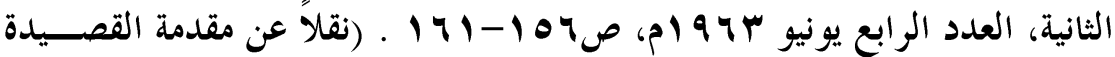

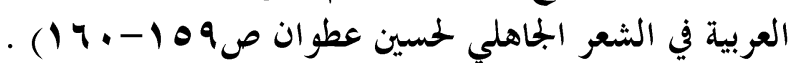

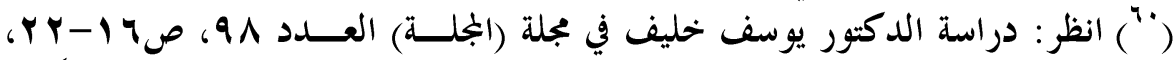

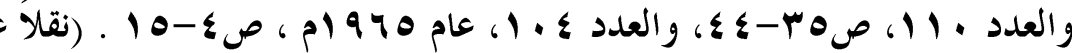

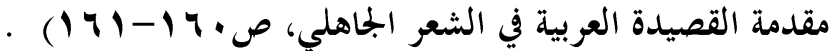

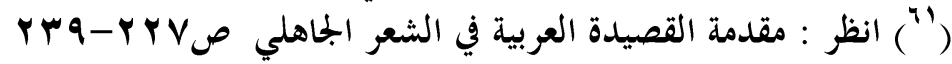

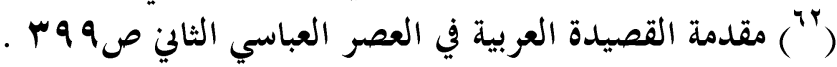

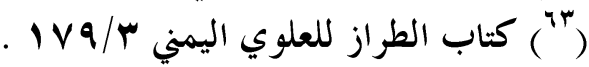

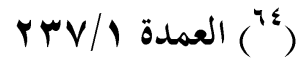

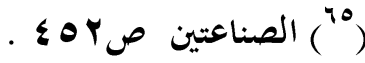

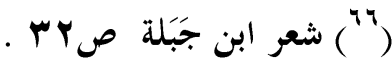




$$
\text { (") }
$$

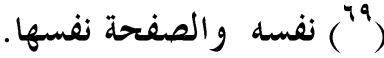

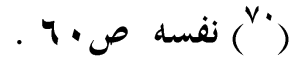

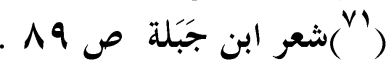

. نفسه صrr

(N) نفسه والصفحة نفسها.

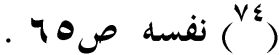

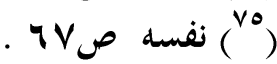

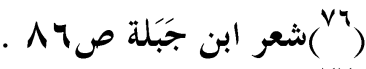

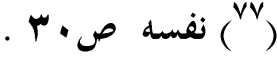

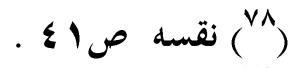

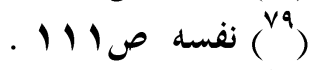

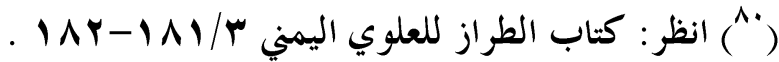

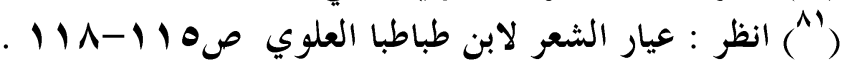

Yr人

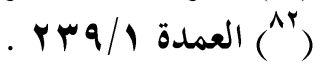

$\overline{3}$
3
2

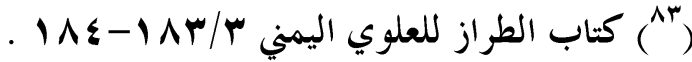

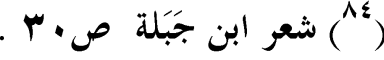

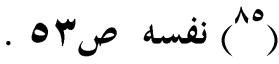

$$
\begin{aligned}
& \text {. }
\end{aligned}
$$

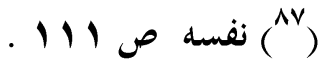

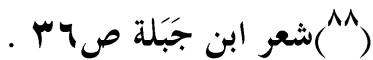

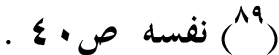

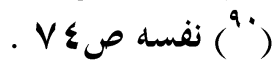

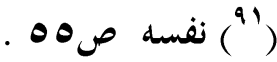

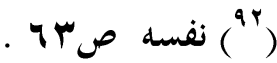

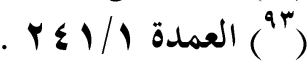$$
\text { ( }
$$

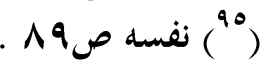$$
\text { . }
$$

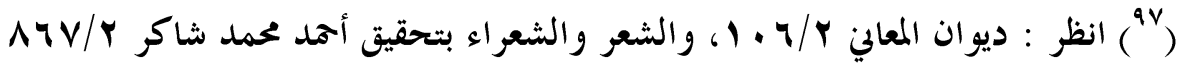

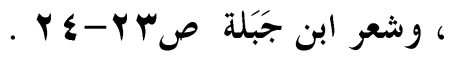




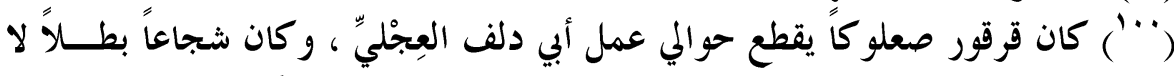

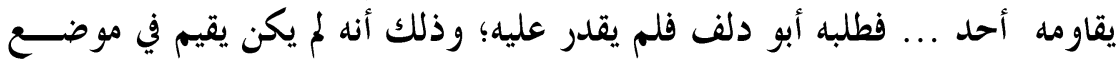

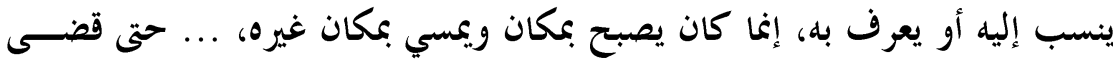

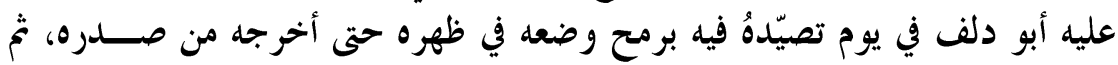

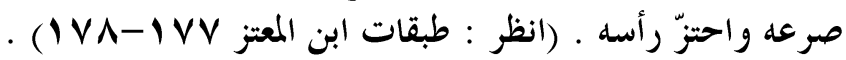

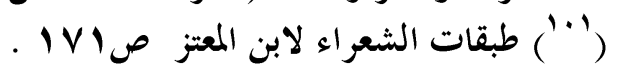
IV^)

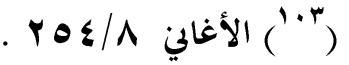

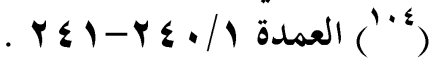

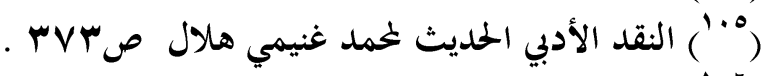

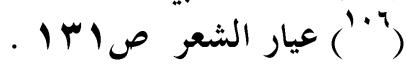

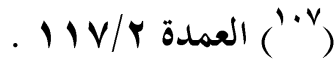
(1.1)

rrq

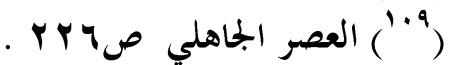

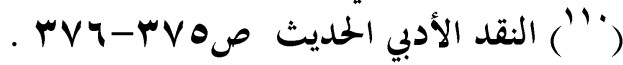

$\overline{3}$
2
2

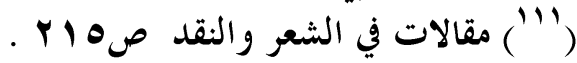

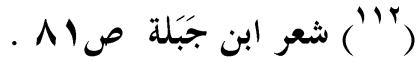

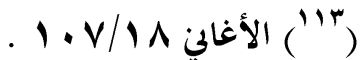

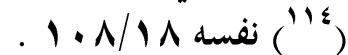

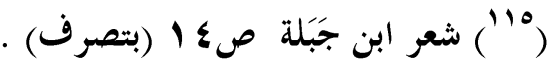
. A (1") . ( ن (IV)

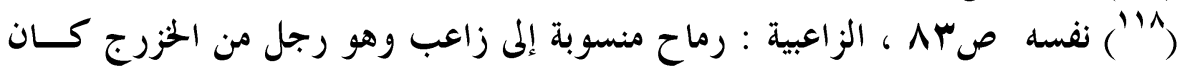

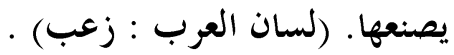

